\title{
Carbon flows through a benthic food web: Integrating biomass, isotope and tracer data
}

\author{
by Dick van Oevelen ${ }^{1,2}$, Karline Soetaert ${ }^{1}$, Jack J. Middelburg ${ }^{1}$, Peter M. J. Herman ${ }^{1}$, \\ Leon Moodley ${ }^{1}$, Ilse Hamels ${ }^{3}$, Tom Moens ${ }^{4}$ and Carlo H. R. Heip ${ }^{1}$
}

\begin{abstract}
The herbivorous, detrital and microbial pathways are major components of marine food webs. Although it is commonly recognized that these pathways can be linked in several ways, elucidating carbon transfers between or within these pathways remains a challenge. Intertidal flat communities are driven by a wide spectrum of organic matter sources that support these different pathways within the food web. Here we reconstruct carbon pathways using inverse analysis based on mass balancing, stable isotope signatures and tracer data. Data were available on biomass, total carbon production and processing, integrated diet information from stable isotope signatures and the transfer of recently produced carbon through the food web from an isotope tracer study. The integration of these data improved the quality of the inverse food web reconstruction considerably, as demonstrated explicitly by an uncertainty analysis. Deposition of detritus (detrital pathway) from the water column and subsequent assimilation and respiration by bacteria and to a lesser extent by microbenthos (microbial pathway) dominated the food web. Secondary production was dominated by bacteria $(600 \mathrm{mg} \mathrm{C}$ $\mathrm{m}^{-2} \mathrm{~d}^{-1}$ ), but transfer to higher trophic levels was limited to $9 \%$ and most bacterial carbon was recycled back to dissolved organic carbon (DOC) and detritus. Microbenthos secondary production (77 $\mathrm{mg} \mathrm{C} \mathrm{m}^{-2} \mathrm{~d}^{-1}$ ) was supported by DOC (73\%) and detritus (26\%) and was entirely transferred up the food web. The higher trophic levels consisting of nematodes, meiobenthos (copepods, ostracods and foraminifera) and macrobenthos fed highly selectively and relied primarily on microphytobenthos and pelagic primary production (herbivorous pathway). Deposit feeding is a common feeding mode among these sediment dwelling fauna, but detritivory was negligible due to this selective feeding. This strong resource selectivity implies that the herbivorous and detrital-microbial pathways function more or less autonomously, with limited interaction.
\end{abstract}

\section{Introduction}

The food web is a central concept in marine ecology and the herbivorous, detrital and microbial pathways are among its major carbon transfers. Much theory is centered around

1. Netherlands Institute of Ecology (NIOO-KNAW), Centre for Estuarine and Marine Ecology, Korringaweg 7, 4401 NT Yerseke, The Netherlands.

2. Corresponding author.email:d.vanoevelen@nioo.knaw.nl

3. Section of Protistology and Aquatic Ecology, Department of Biology, Ghent University, Krijgslaan 281-S8, 9000 Gent, Belgium.

4. Marine Biology Section, Department of Biology, Ghent University, Krijgslaan 281-S8, 9000 Gent, Belgium. 
the herbivorous food chain, in which primary producers sustain higher trophic levels (Ryther, 1969; Steele, 1974). The importance of the detrital pathway has been emphasized by Teal (1962). More recently, the microbial loop was formalized as the transfer of dissolved organic matter, originating from phytoplankton exudation or sloppy feeding (Jumars et al., 1989), through bacterial assimilation and grazing by flagellates to larger zooplankton (Azam et al., 1983). In natural food webs the three pathways are linked in many ways (Polis and Strong, 1996) and elucidating these linkages poses a major challenge in ecology (Legendre and Rassoulzadegan, 1995; Polis and Strong, 1996).

Temperate intertidal flat communities are heterotrophic systems (Heip et al., 1995) and receive carbon inputs from local primary production by microphytobenthos, deposition of high-quality phytodetritus and low-quality organic matter associated with suspended particles from the water column and active filtration by suspension feeders (Herman et al., 1999). The high metabolic activity driven by this wide spectrum of organic matter sources renders intertidal mudflats excellent arenas to study the importance of the different pathways in these food webs.

However, quantifying natural food webs is a universal problem, as methodological and logistical limitations impede simultaneous measurement of all flows. Klepper and Van de Kamer (1987) and Vézina and Platt (1988) pioneered inverse analysis, a data assimilation technique that merges field observations and a priori literature information in a food web structure, to quantify the unmeasured flows. Inverse analysis has been developed in the geophysical sciences (Wunsch and Minster, 1982; Menke, 1984) and has proven to be a robust means to capture the main food web characteristics (Vézina and Pahlow, 2003).

In this paper we first extend the inverse methodology to resolve not only conventional standing stock and process measurements, but also natural abundance stable isotope signatures and transient tracer data. This extended methodology was applied to a large data set on the food web of the Molenplaat intertidal flat (The Netherlands) (Herman et al., 2001). The data set contained different types of data: biomass of the benthos, carbon production and processing (Herman et al., 2001), integrated diet information from stable isotope signatures (Herman et al., 2000; Moens et al., 2002) and tracer data on the fate of recently fixed carbon by microphytobenthos (Middelburg et al., 2000). The use of all these data resulted in a significantly better constrained food web, as shown by uncertainty analysis. The resulting food web characteristics are discussed with respect to the importance of and linkages among the herbivorous, detrital and microbial pathways.

\section{Methods}

\section{a. Study area, food web structure and data}

The Molenplaat intertidal flat is located in the saline part (salinity 20-25) of the turbid, nutrient-rich and heterotrophic Scheldt estuary (Belgium, The Netherlands). The study site (station MP2 in the ECOFLAT-project) has a silt content of 38\% and organic carbon content of $0.70 \% \mathrm{wt} / \mathrm{wt}$. Herman et al. (2001) provide detailed information on the study site. 
The specification of food web compartments is based on the conventional distinction based on size classes (e.g. Schwinghamer, 1981). We consider microphytobenthos, bacteria, microbenthos (i.e. flagellates and ciliates), nematodes and other meiobenthos (copepods, ostracods and foraminifera), and macrobenthos (deposit and suspension feeders) (Fig. 1). Nematodes are treated separately from the other meiobenthos because data on feeding preferences and tracer incorporation were available only for nematodes. Additionally, two abiotic carbon compartments are defined: particulate detritus and dissolved organic carbon (DOC), the latter including extracellular polymeric substances (EPS).

Extensive sampling was conducted between 1996 and 1999. Sediment cores were taken to determine the carbon stocks of detritus and all biotic compartments. Total carbon processing was measured with field and laboratory incubations, yielding data on benthic primary production, bacterial secondary production, bacterivory by microbenthos and community respiration (Table 1). Nematode mouth morphology was investigated to determine feeding preferences of the nematode community (Steyaert et al., 2003).

Natural abundance $\delta^{13} \mathrm{C}$ isotope signatures provide an integrated measure of the different diet contributions to an organism. The $\delta^{13} \mathrm{C}$ of nematodes, meiobenthos and macrobenthos was determined from whole specimens and bacterial $\delta^{13} \mathrm{C}$ was derived from the $\delta^{13} \mathrm{C}$ of bacterial specific Polar Lipid derived Fatty Acids (PLFA) (Table 1). The $\delta^{13} \mathrm{C}$ of detritus was calculated from depth profiles of $\delta^{13} \mathrm{C}$ of total particulate organic matter (Table 1).

The fate of microphytobenthos was quantified by an in situ pulse-chase experiment (Middelburg et al., 2000). A solution of ${ }^{13} \mathrm{C}-\mathrm{HCO}_{3}^{-}$was sprayed on the sediment surface and subsequently fixed by microphytobenthos. The ${ }^{13} \mathrm{C}$ tracer was tracked in microphytobenthos, bacteria, nematodes and macrobenthos, providing quantitative data on the transfer of recently fixed microphytobenthic carbon through the food web.

In addition to site-specific data, a literature review was conducted to obtain quantitative information on processes for which direct field observations were not available. The literature data were used to constrain flows and processes in the food web to biologically realistic bounds. For example, one may impose minimum and maximum constraints on assimilation efficiency or respiration rate (Vézina and Platt, 1988). Constraints were placed on (1) respiration and EPS excretion by microphytobenthos, (2) bacterial growth efficiency, (3) production rates, growth efficiency and assimilation efficiency of microbenthos, nematodes, meiobenthos and macrobenthos and (4) feeding preferences of nematodes and macrobenthos (see Appendix for a complete listing). More specifically, the bacterial growth efficiency $(B G E)$ varies considerably with substrate (del Giorgio and Cole, 1998), therefore the bacterial growth efficiency on DOC (BGEdoc) was assumed to be higher than the bacterial growth efficiency on detritus ( $B G E d e t$ ). The ratio $B G E d o c$ to $B G E d e t$ is fixed to two in order to reduce the number of free parameters in the grid search from 4 to 3 (see below). This saves considerably on simulation time, while still being a good approximation of reality. Respiration flows for microbenthos, nematodes, meiobenthos and macrobenthos are modeled as the sum of two processes: maintenance and growth respiration. Maintenance costs are taken proportional to $1 \%$ of the biomass per day (Fenchel, 1982; Nielsen et al., 1995). 

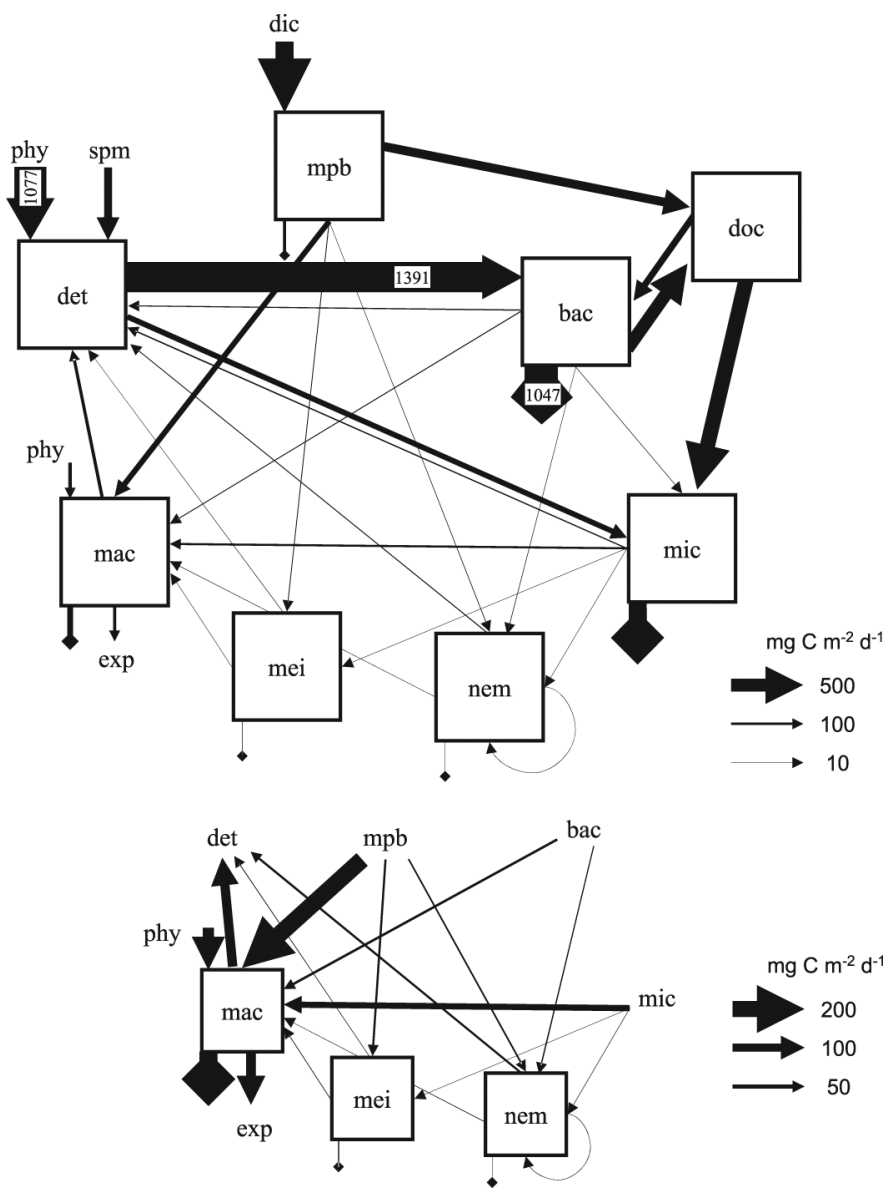

Figure 1. The intertidal food web (CITS). Abbreviations: mpb is microphytobenthos, bac is bacteria, mic is microbenthos, nem is nematodes, mei is meiobenthos, mac is macrobenthos, doc is dissolved organic carbon, det is detritus, phy is phytoplankton, spm is suspended particulate matter, dic is dissolved inorganic carbon and exp is export from the system. Carbon inputs are primary production by microphytobenthos, macrobenthic suspension feeding on phytoplankton, phytoplankton and suspended particulate matter deposition. DOC is produced through EPS excretion by microphytobenthos and bacteria and consumed by bacteria and microbenthos. Detritus is consumed and produced (death and faeces production) by all heterotrophic compartments. Microphytobenthos and bacteria are grazed by microbenthos, nematodes, meiobenthos and macrobenthos. Microbenthos is grazed by nematodes, meiobenthos and macrobenthos, nematodes are grazed by predatory nematodes and macrobenthos, and meiobenthos is grazed by macrobenthos. Carbon outflows are respiration (diamond head arrows), macrobenthic export (e.g. consumption by fish or birds) and bacterial burial. Only non-zero flows are pictured. The arrows with indicated values are not scaled, because their dominance would otherwise mask the thickness differences among the other arrows. The lower panel shows nematodes, meiobenthos and macrobenthos on a different scale to better indicate the flow structure. 
Table 1. Field observations used in the inverse analysis. Depth is the depth of integration. Sources are (1) Middelburg et al. (2000), (2) Hamels et al. (2001b), (3) Hamels et al. (2004), (4) Steyaert et al. (2003), (5) L. Moodley (unpub. data), (6) Herman et al. (2000), (7) Hamels et al. (1998), (8) Dauwe et al. (2001), (9) Moens et al. (2002) and (10) P.M.J Herman (unpub. data).

\section{Compartment name}

microphytobenthos ${ }^{a}$

bacteria

microbenthos

nematodes

microvores

ciliate feeders

deposit feeders

epistrate feeders

facultative predators

predators

meiobenthos

copepods

ostracods

foraminifera

macrobenthos

suspension feeders

deposit feeders

surface deposit feeders

detritus

$\operatorname{doc}^{b}$

\section{Process name}

gross primary production

community respiration

bacterial production $^{c}$

bacterial production

bacterivory microbenthos

\section{Compartment name}

microphytobenthos

bacterial PLFA

nematodes

meiobenthos

macrobenthos

detritus

phytoplankton

suspended particulate matter
Depth (cm)

8.5

4.0

4.0

6.0

1.0

20.0

5.0

Depth (cm)
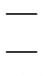

0.3

4.0

4.0

Depth (cm)

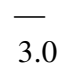

4.0

1.0

20.0

30.0
Stock $\left(\mathrm{mg} \mathrm{C} \mathrm{m}^{-2}\right)$

Source

$$
\begin{gathered}
2090 \\
4097 \\
140 \\
156 \\
4.0 \\
59.2 \\
27.6 \\
25.6 \\
32.8 \\
7.2 \\
259 \\
59.8 \\
38.5 \\
161.1 \\
12172 \\
3639 \\
6270 \\
2264 \\
130660 \\
336
\end{gathered}
$$

1
2
2,3
4

5

6

6
Source

714

7

8

2

2

2

13

Source

${ }^{13} \mathbf{C}$

$-15.0$

6

$-20.4$

$-17.4$

$-15.3$

$-17.8$

$-21.2$

$-21.0$

$-24.0$

\section{1}

9

5

6

10

6

6

${ }^{a}$ Taken from the depth integrated chlorophyll $\alpha$ and assuming a carbon to chlorophyll $\alpha$ ratio of 40 .

${ }^{b}$ Assuming a DOC concentration of $800 \mu \mathrm{mol} \mathrm{C} 1^{-1}$ for porewater and a porosity of 0.70 .

${ }^{c}$ Bacterial production used in the model is integrated to $0.3 \mathrm{~cm}$ (see Results and Discussion). 
Respiration costs related to growth processes can be considerably higher and are modeled as a fixed fraction of assimilated carbon. This fraction equals $1-N G E$, with $N G E$ being the net growth efficiency.

\section{b. Inverse model formulation and uncertainty analysis}

The goal of inverse analysis is to quantify all flows that are present in a food web. The starting point is a topological food web, which defines the mass balance for each compartment in the food web. Subsequently, quantitative information is added to the inverse model, e.g. the sum of respiration flows equals the measured community respiration. Additionally, data from the literature are used to put biologically realistic bounds on the unmeasured flows, e.g. assimilation efficiencies can be constrained within a lower and upper boundary. In this paper we develop the inverse model in three successive steps. First, the conventional methodology is applied, in which data on biomass and total carbon processing are used together with literature data to quantify the food web. Secondly, natural abundance $\delta^{13} \mathrm{C}$ stable isotope data are additionally incorporated in the inverse food web model. Thirdly, data from the transient tracer experiment are assimilated in the food web model. The inverse solutions will be referred to as: CS (Conventional Solution), CIS (Conventional and stable Isotope Solution) and CITS (Conventional, stable Isotope and Tracer Solution). The inverse models are implemented in the modeling environment FEMME (Soetaert et al., 2002) and can be freely downloaded from http://www.nioo.knaw.nl/ceme/femme.

i. Conventional inverse analysis (CS). An inverse model is expressed as (1) a set of linear equality equations

$$
\mathbf{A}_{m, n} \mathbf{x}_{n}=\mathbf{b}_{m}
$$

and (2) a set of linear constraint equations

$$
\mathbf{G}_{m_{c}, n} \mathbf{x}_{n} \geq \mathbf{h}_{m_{c}} .
$$

Each element $\left(x_{i}\right)$ in vector $\mathbf{x}$ represents a flow in the food web. The equality equations contain the mass balances and the field observations, which are all linear functions of the carbon flows (see Table 1 and Appendix). Each row in $\mathbf{A}$ and $\mathbf{b}$ is a mass balance or observation, which are each expressed as a linear combination of the carbon flows. Numerical data enter $\mathbf{b}$, which are the $\frac{d C}{d t}$ of each compartment for each mass balance and the measured data in case of field observations. Here we assume steady-state of the carbon balances (i.e. $\frac{d C}{d t}=0$ ), an assumption that introduces only little error (Vézina and Pahlow, 2003). The constraint equations are used to place upper or lower bounds on single flows or combinations of flows and these bounds will be respected in the inverse solution. The absolute values of the bounds are in vector $\mathbf{h}$ and the constraints coefficients, signifying whether and how much a flow contributes to the constraint, are in matrix $\mathbf{G}$.

Inverse food web models typically have less equality equations than unknown flows (i.e. $m<n$, Vézina and Platt (1988)), which implies that an infinite number of solutions obey the 
equality and constraint equations. The conventional procedure is to select the solution (CS) that is minimal in the sum of squared flows (i.e. $\sum_{i} x_{i}{ }^{2}$ ), which is regarded as the simplest or parsimonious food web (Vézina and Platt, 1988).

ii. Introducing stable isotope data (CIS). Natural abundance stable isotope data are typically interpreted by means of a linear mixing model to estimate relative diet contributions of a consumer (Phillips, 2001; Post, 2002). The $\delta^{13} \mathrm{C}$ signature of a consumer $\left(\delta^{13} C_{j}\right)$ is expressed as a weighted average of the isotope signatures of its resources $\left(\delta^{13} C_{i}\right)$, fractionation $\left(\Delta_{i}\right)$ and the relative contribution of resource $i$ in the diet of consumer $j\left(\alpha_{i}\right)$

$$
{ }^{13} C_{j}=\sum_{i}\left(\left(\delta^{13} C_{i}+\Delta_{i}\right) \cdot \alpha_{i}\right)
$$

With $\alpha_{i}=\frac{\text { flow }_{i \rightarrow j}}{\sum_{i} \text { flow }_{i \rightarrow j}}$, where flow $_{i \rightarrow j}$ is the flow from compartment $i$ to $j$, the relative mixing model can easily be extended to a linear function of the food web flows

$$
\delta^{13} C_{j}=\frac{\sum_{i}\left(\left(\delta^{13} C_{i}+\Delta_{i}\right) \cdot \text { flow }_{i \rightarrow j}\right)}{\sum_{i} \text { flow }_{i \rightarrow j}} .
$$

Fractionation of ${ }^{13} \mathrm{C}$ with trophic level is very small $\sim 0.4 \%$ o (Post, 2002) and is therefore neglected in our inverse model. Hence, when all stable isotope signatures in the food web are known, they are easily implemented in the equality equation (see Appendix). However, when isotope data of some compartments- $\delta^{13} \mathrm{C}$-microbenthos and $\delta^{13} \mathrm{C}$-DOC in our case-are missing a more complicated procedure is required. For this, we developed a grid search technique. The upper and lower $\delta^{13} \mathrm{C}$ value for each missing compartment is assigned based on the food web structure. For example, the possible sources of DOC are bacteria $\left(\delta^{13} \mathrm{C}\right.$ of -20.4) and microphytobenthos $\left(\delta^{13} \mathrm{C}\right.$ of -15.0$)$, which form the respective lower and upper boundaries for $\delta^{13} \mathrm{C}$-DOC. In addition, the parameter $B G E d o c$ should be known in the isotope equation of bacteria (see Appendix). Hence, these three parameters (i.e. $\delta^{13} \mathrm{C}$-microbenthos, $\delta^{13} \mathrm{C}$-DOC and BGEdoc) span a 3-dimensional space of all possible combinations, however these initial ranges are not yet affected by the other information present in the inverse model. To find the combinations of parameters that are compatible with the other data, we performed a grid search. Each parameter range was discretized (step size for isotopes $0.10 \%$ and for $B G E d o c$ 0.05) on a grid and the inverse model solved for every possible parameter combination. When the other data in the inverse model are not compatible with a certain parameter combination, the model residuals are not zero (i.e. the model cannot be solved without deviation from the imposed data). The model residual was calculated as

$$
\text { Residual norm }=(\mathbf{A x}-\mathbf{b})^{T}(\mathbf{A x}-\mathbf{b})+(\mathbf{G x}-\mathbf{h})^{T} \Gamma(\mathbf{G x}-\mathbf{h}) .
$$


$\Gamma$ is a diagonal matrix whose diagonal elements are unity when the argument is negative, and zero when the argument is positive

$$
\Gamma_{i, i}= \begin{cases}0, & (\mathbf{G x}-\mathbf{h})_{i} \geq 0 \\ 1, & (\mathbf{G x}-\mathbf{h})_{i}<0 .\end{cases}
$$

This ensures that only the inequalities that are violated add to the residual norm. By performing this evaluation for each possible parameter combination, one can delineate the possible parameter combinations that are compatible with the other data. The parameter combination that has a zero residual norm and is minimal in $\sum_{i} x_{i}{ }^{2}$ is selected as CIS. This selection procedure makes it possible to find an inverse solution that (1) meets the original definition of simplest or parsimonious food web solution (i.e. minimal in $\sum_{i} x_{i}{ }^{2}$, see Vézina and Platt (1988)) and (2) satisfies conventional and stable isotope data (i.e. residual norm is zero). It is acknowledged that this definition of parsimony has no ecological basis, but it is justified because the standardized procedure facilitates comparison amongst different food web reconstructions (Vézina and Platt, 1988). The search for other selection criteria, e.g. optimization based on ecologically sound criteria (Vézina et al., 2004) or by averaging many different inverse solutions (Kones et al., 2006), is ongoing.

iii. Assimilating deliberate tracer data (CITS). Jackson and Eldridge (1992) simulated the fate of a tracer introduced in a pelagic food web inferred by inverse analysis. This approach inspired us to add the data from the pulse-chase labeling of microphytobenthic carbon (Middelburg et al., 2000).

First, a large set of different inverse food webs was generated by repeatedly solving the inverse model with a weighted cost function $J=\sum_{i} w_{i} x_{i}{ }^{2}$. The cost function minimizes a weighted sum of squared flows. During each run the weighting factors $\left(w_{i}\right)$ were varied, i.e. the elements in $\mathbf{w}$ varied between 1 and 100, such that each run produced an inverse model that was different in its flow values, but all satisfied the conventional and stable isotope data. The uncertainty analysis provides an envelope around each flow, which can be interpreted as the range of values that a flow can attain given a data set (see 'Uncertainty analysis' below for definition). The solutions (in total $>600,000$ ) that were generated with the weighted cost function covered $>91 \%$ of this envelope for each flow (i.e. of the CISrange, see 'Uncertainty analysis' below), except for the flows microbenthos to nematodes (84\% covered) and microbenthos to meiobenthos (73\% covered) (data not shown). Hence, the envelope of each flow was covered sufficiently in our attempt to find the food web that optimally reproduces the tracer data.

Second, each inverse solution was fed to a tracer model that simulates tracer dynamics in each compartment of the food web. Rate constants $\left(\tau_{i \rightarrow j}\right)$ were calculated for each flow by dividing the magnitude of each flow by the size of the source compartment (Jackson and Eldridge, 1992). These rate constants were used to set up the tracer model (see Appendix). In the tracer model the processes respiration, excretion and faeces production have a tracer 
concentration equal to that of the incoming flows. Other outgoing flows, i.e. grazing, predation or export have the tracer concentration of the biotic compartment. To initialize the tracer simulation, the incorporation rate of ${ }^{13} \mathrm{C}-\mathrm{HCO}_{3}^{-}$into microphytobenthos was set to the observed fixation rate of $32 \mathrm{mg}{ }^{13} \mathrm{C} \mathrm{m}^{-2} \mathrm{~h}^{-1}$ during a period of 4.5 hours. The tracer model was solved in the modeling environment FEMME (Soetaert et al., 2002), see http://www.nioo.knaw.nl/ceme/femme for downloads.

Finally, the output of each tracer model was evaluated against the experimental data by means of a weighted cost function

$$
J=\sum_{i=1}^{n v} \sum_{j=1}^{n o}\left(\frac{\operatorname{Mod}_{i j}-O b s_{i j}}{\sigma_{i} \cdot O b s_{i j}}\right)^{2}
$$

where $n v$ is the number of variables, $n o$ is the number of observations, $\operatorname{Mod}_{i j}$ is the modeled value of the observed counterpart $O b s_{i j}$ and $\sigma_{i}$ is the relative weighting factor. Relative errors could not be assessed from the observations but were assigned based on conversion protocols: 0.15 for microphytobenthos and bacteria, 0.10 for nematodes and 0.05 for macrobenthos. Different weighting scenarios were tested but this did not alter the results significantly. The inverse solution that had the lowest cost function was accepted as the CITS.

iv. Uncertainty analysis. In accordance with the three step inverse analysis approach, we calculated the uncertainty for each food web. The uncertainty is expressed as flow ranges of the conventional solution (CSrange), ranges of conventional and stable isotope solution (CISrange) and ranges of conventional, stable isotope and tracer solution (CITSrange). The uncertainty analysis of CSrange and CISrange is based on subsequently minimizing and maximizing each flow by means of linear programming (Vanderbei, 1996) (see Klepper and Van de Kamer, 1987; Stone et al., 1993, for examples of applications in inverse modeling)

$$
\text { minimize } x_{i} \text { and maximize } x_{i}
$$

under the conditions

$$
\mathbf{A x}=\mathbf{b}, \quad \mathbf{G x} \geq \mathbf{h}
$$

This analysis produces an envelope around each flow, which is interpreted as the potential range that a flow can attain given the data specified in the equality (either with or without the isotope signatures) and constraint equations. From all food webs that were run in the tracer model, the best $10 \%$ were used to determine CITSrange. The CITSrange was defined as the minimum and maximum of each flow found within the set of best solutions.

The effect of the uncertainty of the food webs on the tracer dynamics is presented in two ways: (1) as the lower and upper extremes in tracer dynamics found for each compartment when evaluating the large set of generated inverse solutions, therefore this represents the uncertainty in the tracer simulation of CISrange and (2) after assimilating the tracer data as the lower and upper extremes in tracer dynamics for each compartment from the set of $10 \%$ best food webs (CITSrange). 


\section{Results}

\section{a. Inverse solutions and uncertainty analysis}

An initial attempt to solve the inverse model failed as a result of inconsistencies in the field data and literature information. Reconciliation of the depth-integrated bacterial production and community respiration required a bacterial growth efficiency of $>0.66$, far above the imposed limit of 0.32 . The bacterial production measured in the top $3 \mathrm{~mm}$ was consistent with community respiration and was therefore used to solve the inverse model. This is extensively treated in the discussion.

The increasing use of available data resulted in differences among the CS, CIS and CITS and a large decrease in the uncertainty associated with these food web reconstructions. Main differences were found between the CIS and CITS on the one hand and CS on the other hand: $62 \%$ of the flows in CIS and CITS differed more than $\pm 50 \%$ from the CS (Fig. 2A). The large and small flows of the CIS and CITS agree well and differences mainly occur in flows of intermediate magnitude (Fig. 2B). The agreement between CIS and CITS is a clear indication of the internal consistency of the various data sources. The sum of carbon flows increased from 7670 (CS) to 8322 (CIS) to 8398 (CITS) $\mathrm{mg} \mathrm{C} \mathrm{m}^{-2} \mathrm{~d}^{-1}$.

The uncertainty in CS is large: $51 \%$ of the flows has a range of $>500 \mathrm{mg} \mathrm{C} \mathrm{m}^{-2} \mathrm{~d}^{-1}$ and $29 \%$ a range of $>1000 \mathrm{mg} \mathrm{C} \mathrm{m}^{-2} \mathrm{~d}^{-1}$ (Fig. 3). The stable isotope data constrained the uncertainty significantly (Fig. 3): the CISrange for $60 \%$ of the flows decreased with $>50 \%$ as compared to the CSrange and for $34 \%$ of the flows with $>75 \%$. In the CISrange, $25 \%$ of the unknown flows still have a range larger than $200 \mathrm{mg} \mathrm{C} \mathrm{m}^{-2} \mathrm{~d}^{-1}$, but the range for $>50 \%$ of the flows is $<70 \mathrm{mg} \mathrm{C} \mathrm{m}^{-2} \mathrm{~d}^{-1}$. The inclusion of the tracer data constrained some flows more than others (Fig. 3). The CITSrange of $37 \%$ of the flows was $>50 \%$ smaller as compared to their CISrange. In particular, carbon flows related to microphytobenthos, nematodes and macrobenthos were better constrained in the CITSrange. The largest ranges in CITSrange were associated with phytoplankton deposition (between 799 and $1640 \mathrm{mg} \mathrm{C}$ $\mathrm{m}^{-2} \mathrm{~d}^{-1}$ ), detritus uptake by bacteria (between 1314 and $1913 \mathrm{mg} \mathrm{C} \mathrm{m}^{-2} \mathrm{~d}^{-1}$ ) and the fate of ungrazed bacterial production (detritus, DOC or burial; range between 0 and 570 $\mathrm{mg} \mathrm{C} \mathrm{m}{ }^{-2} \mathrm{~d}^{-1}$ ) (Table 2). In addition, flows linked with microbenthos have fairly large ranges: detritus and DOC ingestion by microbenthos have ranges of 555 and $495 \mathrm{mg} \mathrm{C}$ $\mathrm{m}^{-2} \mathrm{~d}^{-1}$ respectively. Detritivorous flows are very well constrained for nematodes $(<1$ $\left.\mathrm{mg} \mathrm{C} \mathrm{m}{ }^{-2} \mathrm{~d}^{-1}\right)$, meiobenthos ( $\left.<5 \mathrm{mg} \mathrm{C} \mathrm{m}^{-2} \mathrm{~d}^{-1}\right)$ and macrobenthos $\left(<40 \mathrm{mg} \mathrm{C} \mathrm{m}^{-2} \mathrm{~d}^{-1}\right)$. Respiration fluxes are well constrained for nematodes (3-8 $\left.\mathrm{mg} \mathrm{C} \mathrm{m}^{-2} \mathrm{~d}^{-1}\right)$, meiobenthos (13-60 mg C m ${ }^{-2} \mathrm{~d}^{-1}$ ) and macrobenthos (226-323 $\mathrm{mg} \mathrm{C} \mathrm{m}^{-2} \mathrm{~d}^{-1}$ ), but less for bacteria (993-1466 $\mathrm{mg} \mathrm{C} \mathrm{m}^{-2} \mathrm{~d}^{-1}$ ) and microbenthos (290-763 $\mathrm{mg} \mathrm{C} \mathrm{m}^{-2} \mathrm{~d}^{-1}$ ). Finally, EPS excretion by microphytobenthos is well constrained and lies between 300 and $398 \mathrm{mg} \mathrm{C}$ $\mathrm{m}^{-2} \mathrm{~d}^{-1}$.

The possible range of modeled tracer dynamics based on solutions drawn from the CISrange was large for microphytobenthos and bacteria, but particularly large for nematodes and macrobenthos (dotted lines in Fig. 4). The possible range of modeled tracer dynamics based 

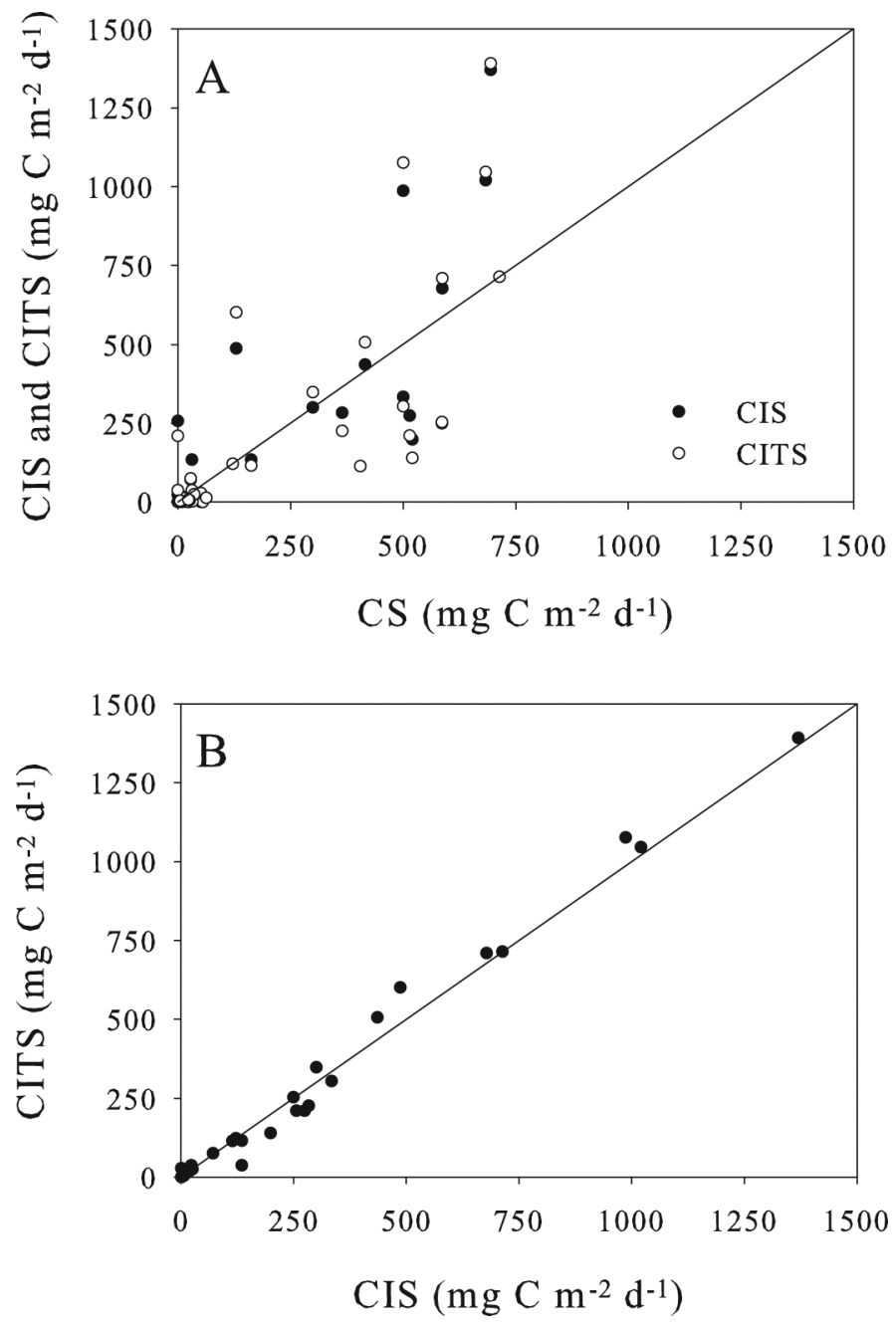

Figure 2. Comparison of (A) CS versus CIS and CITS and (B) CIS versus CITS. The line represents the $1: 1$ relation.

on CITSrange (dotted dashed lines in Fig. 4) was much smaller, especially for nematodes and macrobenthos, due to the fitting to the tracer data. This reduction in the range of tracer dynamics clearly demonstrates that the addition of tracer data further increased the reliability of the reconstructed food web. This increased reliability was also evidenced by the smaller uncertainty of CITSrange as compared to CISrange and CSrange (Fig. 3). The optimal tracer simulation (CITS) describes the entire set of observations quite reasonably. The tracer dynamics of microphytobenthos fit the observations well, which means that the turnover time in our inverse solution is similar to that in the field (Fig. 4). The bacterial tracer 


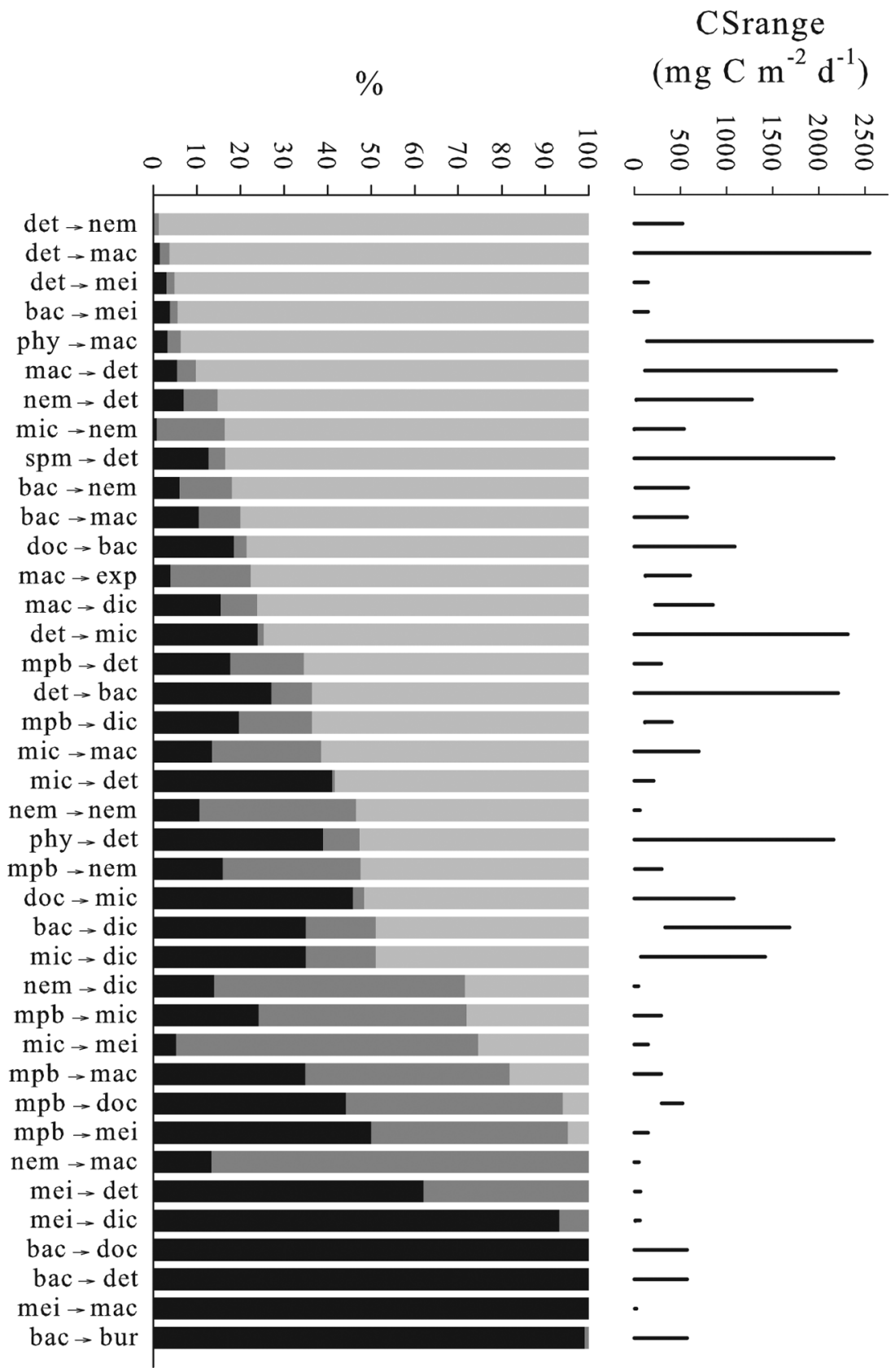

Figure 3. Absolute CSrange for each flow (upper panel) and the relative reduction of this CSrange (light grey) to CISrange (dark grey) or to CITSrange (black) (lower panel). Abbreviations as in Figure 1. 
Table 2. The intertidal benthic food web (CITS) and the associated uncertainty (CITSrange) (mg C $\mathrm{m}^{-2} \mathrm{~d}^{-1}$ ). Flows in italics are field measurements and are therefore fixed in the solution. Abbreviations as in Figure 1 and bur is burial in the sediment.

CITSrange

\begin{tabular}{|c|c|c|c|}
\hline Flow & CITS & $\min$ & $\max$ \\
\hline $\mathrm{doc} \rightarrow \mathrm{bac}$ & 253 & 120 & 322 \\
\hline $\mathrm{doc} \rightarrow \mathrm{mic}$ & 601 & 171 & 666 \\
\hline det $\rightarrow$ bac & 1391 & 1314 & 1913 \\
\hline det $\rightarrow$ mic & 210 & 0 & 555 \\
\hline $\operatorname{det} \rightarrow$ nem & 0 & 0 & 1 \\
\hline det $\rightarrow$ mei & 0 & 0 & 5 \\
\hline $\mathrm{det} \rightarrow \mathrm{mac}$ & 0 & 0 & 40 \\
\hline phy $\rightarrow$ det & 1077 & 799 & 1640 \\
\hline phy $\rightarrow$ mac & 139 & 139 & 218 \\
\hline $\mathrm{spm} \rightarrow$ det & 304 & 264 & 537 \\
\hline $\mathrm{dic} \rightarrow \mathrm{mpb}$ & 714 & 714 & 714 \\
\hline $\mathrm{mpb} \rightarrow$ dic & 114 & 114 & 172 \\
\hline $\mathrm{mpb} \rightarrow \mathrm{doc}$ & 348 & 300 & 398 \\
\hline $\mathrm{mpb} \rightarrow$ det & 0 & 0 & 52 \\
\hline $\mathrm{mpb} \rightarrow \mathrm{mic}$ & 0 & 0 & 71 \\
\hline $\mathrm{mpb} \rightarrow \mathrm{nem}$ & 17 & 17 & 64 \\
\hline $\mathrm{mpb} \rightarrow$ mei & 25 & 23 & 99 \\
\hline $\mathrm{mpb} \rightarrow \mathrm{mac}$ & 210 & 155 & 258 \\
\hline $\mathrm{bac} \rightarrow \mathrm{dic}$ & 1047 & 993 & 1466 \\
\hline $\mathrm{bac} \rightarrow \mathrm{doc}$ & 506 & 0 & 571 \\
\hline $\mathrm{bac} \rightarrow$ det & 37 & 0 & 571 \\
\hline $\mathrm{bac} \rightarrow \mathrm{mic}$ & 13 & 13 & 13 \\
\hline $\mathrm{bac} \rightarrow$ nem & 14 & 14 & 48 \\
\hline $\mathrm{bac} \rightarrow$ mei & 0 & 0 & 6 \\
\hline $\mathrm{bac} \rightarrow \mathrm{mac}$ & 28 & 0 & 59 \\
\hline $\mathrm{bac} \rightarrow$ bur & 0 & 0 & 566 \\
\hline $\operatorname{mic} \rightarrow$ dic & 710 & 290 & 763 \\
\hline mic $\rightarrow$ det & 38 & 0 & 86 \\
\hline $\mathrm{mic} \rightarrow$ nem & 0.4 & 0.4 & 5 \\
\hline mic $\rightarrow$ mei & 2 & 0 & 8 \\
\hline $\mathrm{mic} \rightarrow \mathrm{mac}$ & 75 & 62 & 156 \\
\hline nem $\rightarrow$ dic & 3 & 3 & 8 \\
\hline nem $\rightarrow$ det & 24 & 24 & 112 \\
\hline nem $\rightarrow$ nem & 3 & 2 & 8 \\
\hline nem $\rightarrow$ mac & 4 & 0 & 7 \\
\hline mei $\rightarrow$ dic & 13 & 13 & 60 \\
\hline mei $\rightarrow$ det & 6 & 6 & 43 \\
\hline mei $\rightarrow$ mac & 8 & 8 & 23 \\
\hline $\mathrm{mac} \rightarrow \mathrm{dic}$ & 226 & 226 & 323 \\
\hline $\mathrm{mac} \rightarrow$ det & 116 & 116 & 229 \\
\hline $\operatorname{mac} \rightarrow \exp$ & 122 & 122 & 141 \\
\hline
\end{tabular}


incorporation reproduces the quick response and maximum at 1-2 days. The magnitude of nematode tracer incorporation is very similar to that observed in the field. However the rapid initial enrichment is not reproduced and the modeled incorporation rate seems slightly higher than in the field. Macrobenthos tracer incorporation is overestimated as compared to the one field observation available.

\section{b. Carbon flows in the benthic food web}

Bacteria dominate carbon flows at the Molenplaat and obtain $85 \%$ of their carbon from detritus and the remainder from DOC (Fig. 1 and Table 2). DOC originates from microphytobenthic and bacterial EPS production and bacterial mortality. Bacteria assimilated $2122 \mathrm{mg} \mathrm{C} \mathrm{m}^{-2} \mathrm{~d}^{-1}$ and their growth efficiencies on detritus and DOC were 0.32 and 0.63 , respectively. Only $9 \%$ of the total bacterial production is grazed and the majority of the production is recycled between DOC and bacteria. Microbenthos ingestion ( $825 \mathrm{mg} \mathrm{C}$ $\mathrm{m}^{-2} \mathrm{~d}^{-1}$ ) is mostly DOC (73\%), supplemented with detritus (26\%) and bacteria (2\%). Nematode ingestion ( $35 \mathrm{mg} \mathrm{C} \mathrm{m}^{-2} \mathrm{~d}^{-1}$ ), comprises a small fraction of total heterotrophic ingestion (1\%). The main nematode food sources are microphytobenthos (50\%) and bacteria (39\%). Nematode predation forms $10 \%$ of total nematode ingestion. The other meiobenthos (i.e. ostracods, copepods and foraminifera) play a marginal role in carbon cycling; the ingestion rate is restricted to $27 \mathrm{mg} \mathrm{C} \mathrm{m}^{-2} \mathrm{~d}^{-1}$ (1\% of total heterotrophic ingestion), with dominant carbon sources being microphytobenthos (93\%) followed by microbenthos (7\%). As they have a high biomass, macrobenthos play an important role in carbon cycling and their ingestion is around $15 \%$ of total heterotrophic ingestion. Important macrobenthic carbon sources are microphytobenthos (45\%) and phytoplankton (30\%). Ingestion of bacteria $(6 \%)$, microbenthos $(16 \%)$, nematodes $(1 \%)$ and meiobenthos $(2 \%)$ completes their diet. Surprisingly, the results show no ingestion of detritus by nematodes, meiobenthos and macrobenthos.

The heterotrophic Molenplaat receives carbon inputs from suspended particulate matter deposition (14\%), local primary production by microphytobenthos $(32 \%)$, suspension feeding by macrobenthos $(6 \%)$ and phytoplankton deposition (48\%) (Table 2). Community respiration is dominated by bacterial respiration (50\%) with microbenthos as second contributor (34\%). The contribution to respiration by other compartments is smaller with $11 \%$ for macrobenthos, $5 \%$ for microphytobenthos and $<1 \%$ for nematodes and meiobenthos (Table 2). Secondary carbon production, defined for compartment $j$ as $\sum_{i}$ flow $_{i \rightarrow j}-$ flow $_{j \rightarrow \text { det }}-$ flow $_{j \rightarrow \text { dic }}$, by the benthic community amounts to $826 \mathrm{mg} \mathrm{C}$ $\mathrm{m}^{-2} \mathrm{~d}^{-1}$ and is again dominated by bacteria (74\%), followed by macrobenthos $(15 \%)$, microbenthos (10\%), nematodes $(1 \%)$ and other meiobenthos $(1 \%)$.

\section{Discussion}

The Molenplaat is one of the best-studied intertidal flats with comprehensive data on its physical, chemical and biological characteristics (Herman et al., 2001). Despite this 

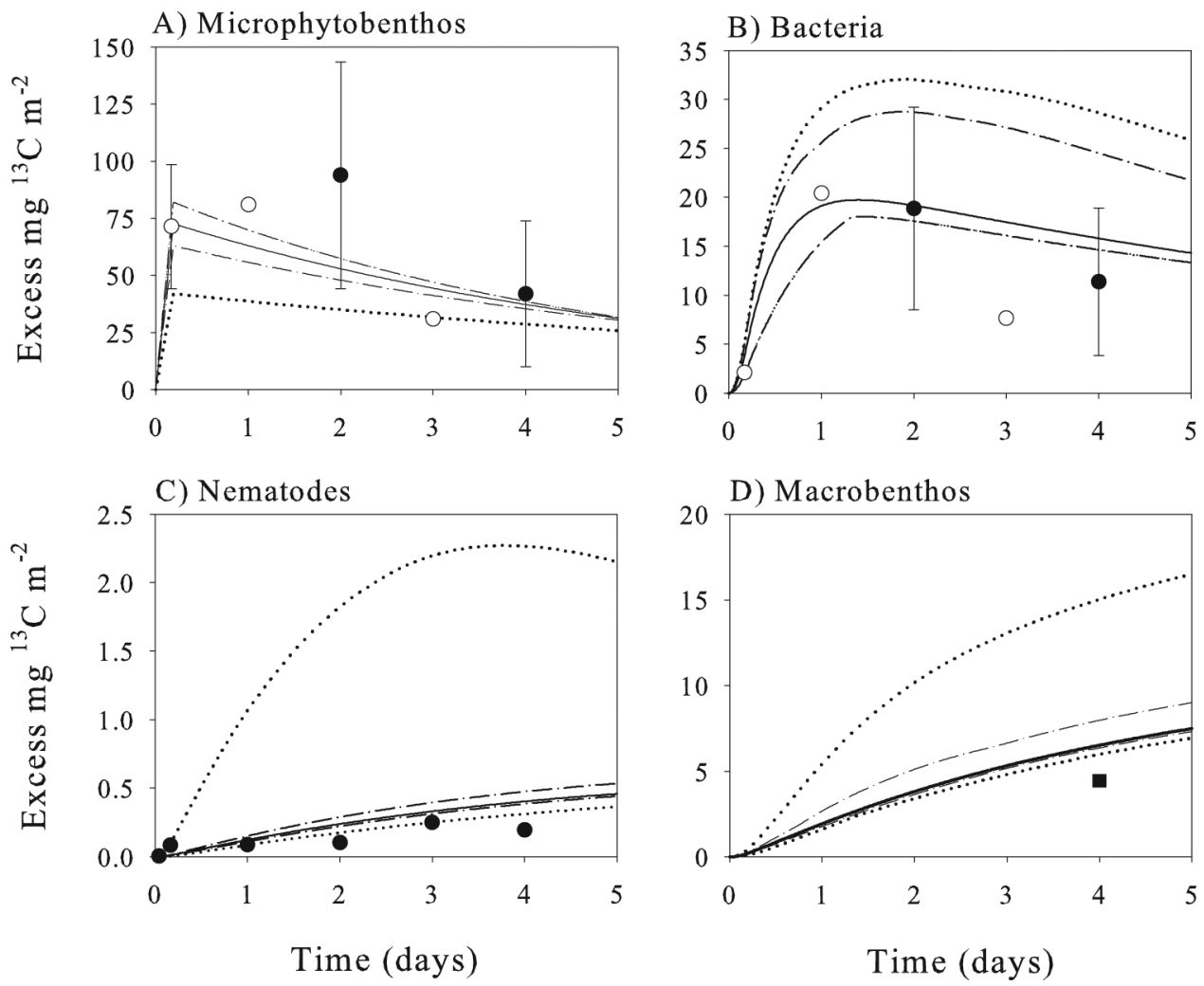

Figure 4. Tracer dynamics in the Molenplaat as measured in the top $5 \mathrm{~mm}$ (open circles), top $20 \mathrm{~mm}$ (filled circles) and top $20 \mathrm{~cm}$ (filled squares) and simulated based on the CITS (dark line). Also indicated are the range of tracer dynamics based on CISrange (dotted lines) and CITSrange (dashed dotted lines). The upper tracer dynamics ranges for CISrange and CITSrange overlap for microphytobenthos, while the lower ranges overlap for bacteria. When present, error bars denote standard deviations.

extensive data set, producing a 'coherent and well-constrained' food web was ambiguous. This ambiguity relates to data quality and availability and to the inverse methodology. Hence, these will be discussed first, followed by a discussion on the importance of the herbivorous, detrital and microbial pathways in the benthic food web.

\section{a. Field data}

i. Spatial and temporal variation in the data set. There is considerable temporal and spatial segregation in the data set. The data have been collected in the period 1996-1999. Some measurements were performed only once (e.g. $\delta^{13} \mathrm{C}$ signatures and meiobenthic biomass), others are season-averaged (e.g. bacterial production, bacteria and microbenthos 
stock) and sampling depth ranged from $0-1 \mathrm{~cm}$ (meiobenthos) to $0-20 \mathrm{~cm}$ (macrobenthos). These temporal and spatial differences in data acquisition may partly explain some of the encountered discrepancies, but unfortunately this problem is inherent to many ecosystem approaches and food web reconstructions. However, several studies indicate no major changes in microphytobenthic (Hamels et al., 1998), meiobenthic (M. Steyaert, pers. com.) and macrobenthic (Herman et al., 2000) biomass and composition during the study period. Moreover, most biomass and/or production for the biotic compartments microphytobenthos (Hamels et al., 1998; Middelburg et al., 2000; Hamels et al., 2004), bacteria (Hamels et al., 2001b), microbenthos (Hamels et al., 2004), nematodes (Steyaert et al., 2003) and macrobenthos (Herman et al., 2000) occur within the reported integration depth of the respective compartment and therefore the biological active zone of most compartments is included in the model.

ii. Bacterial production and community respiration. The inverse methodology identified the inconsistency of depth-integrated bacterial production (BP) with sediment community oxygen consumption (SCOC). Even when assuming that all respiration is bacterial, anomalously high growth efficiencies are needed. This inconsistency has frequently been reported in studies measuring both BP and SCOC (Van Duyl and Kop, 1990; Cammen, 1991; Alongi, 1995). Some potential problems with BP measurements are unbalanced growth and nonspecificity or catabolism of the radioactive substrate that is added to measure BP (Kemp, 1990). Moreover, BP is based on comparatively short incubations ( $\sim 30$ minutes). Compared to these uncertainties, SCOC measurements are more robust (Dauwe et al., 2001). SCOC integrates aerobic (direct oxygen consumption) and anaerobic (re-oxidation of reduced compounds) mineralization pathways over a time scale in the order of days to weeks. The SCOC based on intact contact core incubations ranged from 1806 to $2406 \mathrm{mg} \mathrm{C} \mathrm{m}^{-2} \mathrm{~d}^{-1}$ and compares well with independent community respiration measurements based on $\mathrm{CO}_{2}$ production in slurry incubations ( $2400 \mathrm{mg} \mathrm{C} \mathrm{m}^{-2} \mathrm{~d}^{-1}$ ) (Dauwe et al., 2001). As two different SCOC measures gave similar results and SCOC integrates heterotrophic activity over a longer time scale than BP measurements, it is therefore taken as the most appropriate measure to constrain total benthic activity at the expense of the depth integrated BP. Recently, Van Oevelen et al. (2006) executed a long-term in situ ${ }^{13} \mathrm{C}$-glucose labeling experiment and derived a BP of $798 \mathrm{mg} \mathrm{C} \mathrm{m}^{-2} \mathrm{~d}^{-1}$ for the top $10 \mathrm{~cm}$ of the sediment, which compares favorably to the BP adopted here (598 $\left.\mathrm{mg} \mathrm{C} \mathrm{m}^{-2} \mathrm{~d}^{-1}\right)$.

iii. Bacterial $\delta^{13} C$ signature. Direct measurement of the $\delta^{13} \mathrm{C}$ of bacterial biomass from field samples is currently impossible and can only be assessed using bacterial biomarkers such as specific bacterial fatty acids (PLFAs) as proxies (Boschker and Middelburg, 2002). A critical question is whether the isotope signature of biomarkers reflects that of total bacterial biomass. In a review of culture studies on Escherichia coli, Hayes (2001) concludes that PLFAs are typically depleted by 3 to $8 \%$ compared to total bacterial biomass. A depletion of 4 to $6 \%$ for the PLFAs i14:0, i + a15:0 has been found in culture studies using an inoculate of a natural bacterial community (Boschker et al., 1999) and a depletion of 
$3.7 \%$ has been reported from a large data set comparing the $\delta^{13} \mathrm{C}$ of $\mathrm{i}+\mathrm{a} 15: 0$ with the $\delta^{13} \mathrm{C}$ of POC (Bouillon and Boschker, 2006). However, these estimates come with a high degree of variation ranging from +4 to $-8 \%$ and it is unclear whether these results may be translated to the field (Bouillon et al., 2004), as fractionation depends among other things on the relative abundance of lipids (Hayes, 2001), substrate utilization (DeNiro and Epstein, 1977) and oxygen concentration (Teece et al., 1999). Alternatively, it has been suggested that the average $\delta^{13} \mathrm{C}$ of different PLFA is a good indicator of microbial substrate use in soils (Burke et al., 2003). We chose the latter approach for two reasons. First, assuming a typical depletion of 3 to $5 \%$ could not be resolved with respect to the other observations. Second, such heavy bacterial $\delta^{13} \mathrm{C}$ values would point to microphytobenthos as the dominant carbon source for bacteria, which is unlikely as (1) bacterial respiration outbalances microphytobenthos production and (2) the $\delta^{13} \mathrm{C}$ of bacterial biomarkers did not show a depth gradient. However, we investigated the impact of this assumption on the main findings reported in this paper by solving the CIS model with a depletion factor of $2.0 \%$ o (i.e., $\delta^{13} \mathrm{C}$-bacteria $=-18.4 \%$ ). This depletion could be resolved with the other data and is a reasonable depletion factor given the scatter that surrounds most depletion estimates. The 'depleted' CIS was very comparable with the reported CITS and therefore applying a moderate depletion factor does not change the major findings presented in this paper. The major difference with the reported CITS was that more DOC was taken up by bacteria and less by microbenthos and less detritus was taken up by bacteria and more by microbenthos.

\section{b. Extended inverse methodology, stable isotopes and tracer data}

Inverse models are increasingly used to quantify food webs (e.g. Niquil et al., 1998; Breed et al., 2004). In this paper, an intertidal food web was quantified with the inverse method based on conventional data on carbon processing to obtain a conventional solution (CS). The uncertainty that surrounds a flow in the CS was obtained by determining the possible range of values that each flow can have given the conventional data set (CSrange). The uncertainty in CSrange was high for many of the food web flows (Fig. 3). To decrease this uncertainty, linear mixing equations of natural abundance $\delta^{13} \mathrm{C}$ were added to the inverse model to obtain the inverse solution with conventional and stable isotope data (CIS). The uncertainty in CIS was obtained again by range estimation (CISrange) and it appeared that the uncertainty in the reconstruction was much with the isotope data (CISrange) was much smaller as compared to CSrange (Fig. 3). However, a major problem in inverse modeling of food webs is that the final inverse solution is selected based on an arbitrary parsimony criterium, which is defined as the solution that is minimal in the sum of squared flows (Vézina and Platt, 1988). Also the CS and CIS are based on this parsimony principle. Tracer data were used to make this parsimony principle redundant. Many different food webs were drawn from CISrange and were fed to a tracer model to produce tracer dynamics for each compartment. These modeled tracer dynamics were contrasted against tracer data that were available from a field 
experiment. The CIS that optimally fitted the tracer data was promoted to the final inverse solution and was based on conventional, stable isotope and tracer data (CITS). Since the CITS is selected by fitting to field data, the parsimony principle that was used to select CS and CIS was made redundant.

Mixing models are increasingly used in ecology to estimate diet contributions of $x+1$ resources from $x$ different isotopes (Phillips, 2001; Post, 2002). When more than $x+1$ resources are available to a consumer, it is impossible to uniquely estimate the resource diet contributions based on $x$ different isotopes. For such situations, Phillips and Gregg (2003) propose a grid search technique to estimate a feasible range and frequency distribution for the diet contributions of different resources, rather than calculating a unique solution. In our study we similarly take advantage of a grid search technique (see Materials and methods), but use data on total carbon processing as additional constraints. This serves two purposes. First, while previous isotope applications have been very fruitful in quantifying the relative contribution of a resource, we also quantify the absolute magnitude of all food web flows. Second, combining stable isotope and total carbon processing data increases the data resolution such that the uncertainty in the food web decreases. Recently, Eldridge et al. (2005) added stable isotope data to the constraint equation (2) of an inverse food web model rather than the equality equation (1) as presented here.

The integration of tracer experiments and modeling has proven to provide quantitative insight in food web interactions (Cole et al., 2002; Van den Meersche et al., 2004). Although the data from the tracer experiment provided quantitative information on the transfer of recently fixed carbon (Middelburg et al., 2000), sampling in itself was insufficient to quantify all food web flows. Instead, a tracer model was used to identify the inverse solution that optimally reproduced these tracer data. In general, the correspondence between model and data is acceptable (Fig. 4). The correspondence for microphytobenthos suggests that its turnover time and the fraction of the primary production excreted as EPS are accurately modeled. The general data-model agreement for bacteria gives credit to our previously discussed assumptions regarding bacterial production and bacterial $\delta^{13} \mathrm{C}$. Although the magnitude of nematode labeling is reproduced by the model, the incorporation lags slightly behind the observations. This may be explained by ingestion of DOC (not modeled) or selective ingestion of active, highly labeled microphytobenthos cells. Macrobenthic label incorporation, measured at the end of the experiment, was overestimated by a factor 1.5. Two explanations may apply. First, due to the limited spatial scale of the experiment, 30\% of the deposit feeders (e.g. Arenicola marina) were not present in the samples from the tracer experiment and their label incorporation could not be assessed. Second, animals may have migrated into and out of the small enriched plots, thereby causing a net efflux of label from the experimental plots (Herman et al., 2000). As there is only one observation and two plausible explanations for an overestimation of modeled label incorporation, we feel that the discrepancy is not strong enough to question the results.

The addition of stable isotope and tracer data changed the solutions, $62 \%$ of the flows in CIS and CITS differed more than $\pm 50 \%$ from the CS. The sum of carbon flows increased 
from 7670 (CS) to 8322 (CIS) to 8398 (CITS) $\mathrm{mg} \mathrm{C} \mathrm{m}^{-2} \mathrm{~d}^{-1}$, corroborating the results from twin-modeling that show underestimation of flows in the parsimonious solution in recycling webs (Vézina and Pahlow, 2003). Moreover, inclusion of tracer data in the inverse solution made the parsimonious criterium redundant. The CITS food web is therefore free from bias introduced by such a criterium (Niquil et al., 1998). Finally, the integration of biomass, process, stable isotope and tracer data significantly reduced the uncertainty in the food web reconstruction.

\section{c. Pathways in the benthic food web}

The biomass of bacteria, microbenthos, meiobenthos and macrobenthos in the Molenplaat can be considered representative for temperate estuarine tidal flats (Heip et al., 1995; Soetaert et al., 1995; Herman et al., 1999). This also holds for bacterial production (Van Duyl and Kop, 1990), primary production and sediment oxygen consumption (Heip et al., 1995; Herman et al., 1999). Accordingly, the food web structure and functioning can be generalized and in this last section we discuss the importance of the herbivorous, detrital and microbial pathways.

i. Herbivorous pathway. The primary producers microphytobenthos and phytoplankton supported nematodes, other meiobenthos and macrobenthos in this heterotrophic benthic food web. Recent studies of food webs in estuaries (Thompson and Schaffner, 2001; Sobczak et al., 2002; Chanton and Lewis, 2002), streams (Tank et al., 2000) and lakes (Cole et al., 2002) report a similar dominant contribution of autochthonous production in diets of metazoan grazers.

Microphytobenthos excrete $49 \%$ of their carbon production as EPS, which enters the food web as dissolved organic carbon.

ii. Microbial pathway. Bacteria dominate carbon flows and account for $74 \%$ of the total secondary production and $50 \%$ of the total respiration. This agrees with earlier reports on the bacterial dominance of production (Schwinghamer et al., 1986; Chardy and Dauvin, 1992) and respiration (Smith, 1973; Schwinghamer et al., 1986; Moodley et al., 2002). Grazing by higher trophic levels on bacteria is restricted and therefore bacterial production appears to be a sink rather than a link of carbon in the food web. This conclusion is supported by recent experimental evidence from an in situ ${ }^{13} \mathrm{C}$ labeling experiment conducted at this study site (Van Oevelen et al., 2006). Other short-term grazing studies on bacterivory by micro-, meio- or macrobenthos reported a similar limited transfer of bacterial carbon production (Kemp, 1987; Epstein and Shiaris, 1992; Hondeveld et al., 1995). The fate of bacterial production, other than grazing, was poorly constrained. Bacterial carbon may be recycled back to DOC or detritus or buried in the sediment. Recent papers indicate that bacterial biomass and production rates are closely coupled to the distribution of viruses (Paul et al., 1993; Fischer et al., 2003), which may explain the recycling fluxes to the abiotic compartments. However, burial of recalcitrant bacterial cell-wall remnants has 
been observed in ocean margin sediments (Grutters et al., 2002), but it is unknown whether this is a quantitatively important sink of bacterial production.

Microbenthos has a comparatively high carbon demand due to their high specific production and low growth efficiency. Their low rate of bacterivory implies that bacteria constitute $2-3 \%$ of their diet. This is surprisingly low, given that microbenthos biomass is dominated by flagellates and these are typically seen as bacterivores. Consequently, either other carbon sources form their main food source or reported production rates are overestimates for field situations. The contributions of other resources (microphytobenthos, detritus and DOC) are poorly constrained, but DOC seems to form an important resource for microbenthos. Although flagellates are known for their capability to use dissolved organic substances (Sherr, 1988), its significance in sediments remains to be established. Microbenthos carbon production was transferred higher up the food web to nematodes $(<1 \%)$, meiobenthos (3\%) and macrobenthos (97\%). Hamels et al. (2001a) indeed found a transfer of microbenthic carbon to nematodes for an intertidal sandy site. Hence, the microbial loop seems to have a dead end in bacteria, but there is potential transfer of DOC through microbenthos to higher trophic levels.

iii. Detrital pathway. The semi-labile detritus supported the majority of bacterial carbon production and some of the microbenthos production. The rapid transfer of ${ }^{13} \mathrm{C}$ tracer to bacteria observed in the labeling experiment is fully explained by labile EPS excretion by microphytobenthos to the DOC pool and subsequent assimilation by bacteria. However, DOC represents only $15 \%$ of the total bacterial carbon demand. The importance of semilabile detritus for bacterial production found in this intertidal flat food web can be explained from a biogeochemical viewpoint. Oxygen is rapidly consumed in the top millimeters of coastal sediments. Detritus is therefore predominantly degraded in the bacterial domain of suboxic and anoxic metabolic pathways (e.g. Canfield et al., 1993). Moreover, the labile part of detritus is degraded in the top layer of the sediment and therefore the most likely bacterial resource under suboxic/anoxic conditions is semi-labile detritus.

Although the intertidal flat food web supports a large population of supposedly deposit feeding nematodes, meiobenthos and macrobenthos, these organisms appear to selectively assimilate high quality resources such as microphytobenthos, phytoplankton and to a lesser extent bacteria. Selective assimilation of high quality carbon has been demonstrated directly using ${ }^{13} \mathrm{C}$ labeled phytodetritus (Blair et al., 1996; Levin et al., 1999; Moodley et al., 2002; Witte et al., 2003). This high selectivity suggests that bulk organic matter is a poor indicator of resource availability for deposit feeding organisms and refined descriptions based on organic matter quality are required for estimates of food availability (Dauwe et al., 1999).

The conceptual model of Mayer et al. (2001) is especially interesting when trying to explain the observed resource partitioning among bacteria and higher organisms. They relate digestive differences between deposit feeders (digestive tract) and bacteria (extracellular enzymes) to resource quality and suggest that deposit feeders benefit from high 
quality resources, while bacteria can better handle low quality resources. Whether this explains our results is an intriguing, yet open question.

In summary, we find two major food web pathways in our intertidal flat with comparatively limited interaction. The semi-labile detrital pathway dominates carbon flows in the food web and supports the majority of the bacterial secondary production. Transfer of bacterial carbon to higher trophic levels is very restricted and instead recycles back to detritus and DOC. The herbivorous pathway is the second dominant pathway, in which microphytobenthos and phytoplankton supply labile carbon to the food web. Nematodes, meiobenthos and macrobenthos selectively feed on this particulate carbon production. Although many species in these benthos groups classify as deposit feeder, this selectivity results in a virtual absence of detritivory. The observed separation of carbon pathways suggests that they function rather autonomously.

Acknowledgments. We thank our ECOFLAT colleagues for a stimulating research environment. Filip Meysman, Alain Vézina and three anonymous reviewers are acknowledged for their constructive feedback. This research was partially supported by the European Union (Project ENV 4-CT96-0216), the Flemish Fund for Scientific Research (postdoctoral fellowship to T.M.) and the Netherlands Organization for Scientific Research (Projects 833.02.2002 and 832.11.011). This is publication 3822 of the Netherlands Institute of Ecology, Yerseke.

\section{APPENDIX}

\section{Inverse model equations, inverse model constraints and tracer model equations}

This Appendix contains all inverse model equations (Table A1), inverse model constraints (Table A2) and tracer model equations (Table A3).

Table A.1. Inverse model equations. Abbreviations: $m p b$ is microphytobenthos, $b a c$ is bacteria, $m i c$ is microbenthos, nem is nematodes, mei is meiobenthos, mac is macrobenthos, doc is dissolved organic carbon, det is detritus, dic is dissolved inorganic carbon, phy is phytoplankton, spm is suspended particulate matter, exp is export and bur is burial. All mass balances are assumed to be in steady state. Flows are designated as source $\rightarrow$ sink.

Mass balances

$$
\begin{aligned}
& \frac{d m p b}{d t}=0=d i c \rightarrow m p b-m p b \rightarrow d i c-m p b \rightarrow d o c-m p b \rightarrow \text { det } \\
& -m p b \rightarrow \text { mic }- \text { mpb } \rightarrow \text { nem }- \text { mpb } \rightarrow \text { mei }- \text { mpb } \rightarrow \text { mac } \\
& \frac{d b a c}{d t}=0=d o c \rightarrow b a c+d e t \rightarrow b a c-b a c \rightarrow d i c-b a c \rightarrow d o c-b a c \rightarrow d e t \\
& - \text { bac } \rightarrow \text { bur }- \text { bac } \rightarrow \text { mic }- \text { bac } \rightarrow \text { nem }- \text { bac } \rightarrow \text { mei }- \text { bac } \rightarrow \text { mac } \\
& \frac{d m i c}{d t}=0=m p b \rightarrow m i c+b a c \rightarrow m i c+d o c \rightarrow m i c+d e t \rightarrow \text { mic }- \text { mic } \rightarrow \text { dic } \\
& - \text { mic } \rightarrow \text { det }- \text { mic } \rightarrow \text { nem }- \text { mic } \rightarrow \text { mei }- \text { mic } \rightarrow \text { mac } \\
& \frac{d n e m}{d t}=0=m p b \rightarrow n e m+b a c \rightarrow n e m+\text { mic } \rightarrow \text { nem }+ \text { det } \rightarrow \text { nem }- \text { nem } \rightarrow \text { dic } \\
& - \text { nem } \rightarrow \text { det }- \text { nem } \rightarrow \text { mac } \\
& \frac{d m e i}{d t}=0=m p b \rightarrow m e i+b a c \rightarrow m e i+m i c \rightarrow m e i+d e t \rightarrow m e i-m e i \rightarrow d i c \\
& -\mathrm{mei} \rightarrow \mathrm{det}-\mathrm{me} i \rightarrow \mathrm{mac} \\
& \frac{d m a c}{d t}=0=m p b \rightarrow m a c+b a c \rightarrow m a c+m i c \rightarrow m a c+n e m \rightarrow m a c+m e i \rightarrow m a c
\end{aligned}
$$


Table A.1. (Continued)

$$
\begin{aligned}
& + \text { det } \rightarrow \text { mac }+ \text { phy } \rightarrow \text { mac }- \text { mac } \rightarrow \text { dic }- \text { mac } \rightarrow \text { exp } \\
& \frac{d d o c}{d t}=0=m p b \rightarrow d o c+b a c \rightarrow d o c-d o c \rightarrow b a c-d o c \rightarrow \text { mic } \\
& \frac{d d e t}{d t}=0=p h y \rightarrow \operatorname{det}+s p m \rightarrow \operatorname{det}+m p b \rightarrow \operatorname{det}+b a c \rightarrow d e t+\text { mic } \rightarrow \text { det } \\
& +\mathrm{nem} \rightarrow \mathrm{det}+\mathrm{mei} \rightarrow \mathrm{det}+\mathrm{mac} \rightarrow \mathrm{det}-\mathrm{det} \rightarrow \mathrm{bac}-\mathrm{det} \rightarrow \mathrm{mic} \\
& - \text { det } \rightarrow \mathrm{nem}-\mathrm{det} \rightarrow \mathrm{mei}-\mathrm{det} \rightarrow \mathrm{mac}
\end{aligned}
$$

Isotope mass balances

$$
\begin{aligned}
& \delta^{13} C-b a c=\frac{B G E d o c \cdot d o c \rightarrow b a c}{B G E d o c \cdot d o c \rightarrow b a c+B G E d e t \cdot d e t \rightarrow b a c} \cdot \delta^{13} C-d o c \\
& +\frac{B G E \text { det } \cdot \text { det } \rightarrow \text { bac }}{\text { BGEdoc.doc } \rightarrow \text { bac }+ \text { BGEdet } \cdot d e t \rightarrow b a c} \cdot \delta^{13} C \text {-det } \\
& \delta^{13} C-m i c=\frac{d o c \rightarrow m i c}{d o c \rightarrow m i c+d e t \rightarrow m i c+m p b \rightarrow m i c+b a c \rightarrow \text { mic }} \cdot \delta^{13} C-d o c \\
& +\frac{\operatorname{det} \rightarrow \text { mic }}{d o c \rightarrow \text { mic }+\operatorname{det} \rightarrow \text { mic }+m p b \rightarrow \text { mic }+b a c \rightarrow m i c} \cdot \delta^{13} C \text {-det } \\
& +\frac{m p b \rightarrow m i c}{d o c \rightarrow m i c+d e t \rightarrow m i c+m p b \rightarrow m i c+b a c \rightarrow m i c} \cdot \delta^{13} C-m p b \\
& +\frac{b a c \rightarrow m i c}{d o c \rightarrow m i c+d e t \rightarrow m i c+m p b \rightarrow m i c+b a c \rightarrow m i c} \cdot \delta^{13} C-b a c \\
& \delta^{13} \mathrm{C} \text {-nem }=\frac{\text { det } \rightarrow \text { nem }}{\text { det } \rightarrow \text { nem+mpb } \rightarrow \text { nem }+ \text { bac } \rightarrow \text { nem }+ \text { mic } \rightarrow \text { nem }} \cdot \delta^{13} C \text {-det } \\
& +\frac{\mathrm{mpb} \rightarrow \text { nem }}{\text { det } \rightarrow \text { nem }+ \text { mp } \rightarrow \text { nem+bac } \rightarrow \text { nem }+ \text { mic } \rightarrow \text { nem }} \cdot \delta^{13} \mathrm{C}-\mathrm{mpb} \\
& +\frac{b a c \rightarrow n e m}{d e t \rightarrow n e m+m p b \rightarrow n e m+b a c \rightarrow n e m+m i c \rightarrow n e m} \cdot \delta^{13} C \text {-bac } \\
& +\frac{\text { mic } \rightarrow \text { nem }}{\text { det } \rightarrow \text { nem }+ \text { mpb } \rightarrow \text { nem }+ \text { bac } \rightarrow \text { nem }+ \text { mic } \rightarrow \text { nem }} \cdot \delta^{13} \text { C-mic }
\end{aligned}
$$

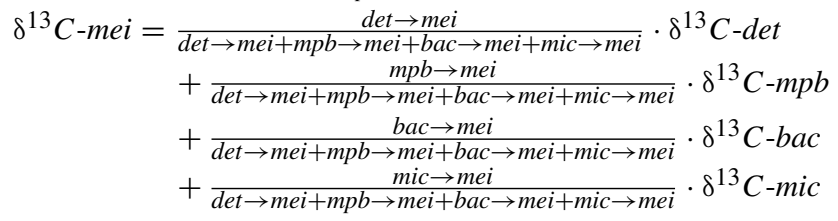

$$
\begin{aligned}
& \delta^{13} C-m a c=\frac{d e t \rightarrow m a c}{d e t \rightarrow m a c+p h y \rightarrow m a c+m p b \rightarrow m a c+b a c \rightarrow m a c+m i c \rightarrow m a c+n e m \rightarrow m a c+m e i \rightarrow m a c} \cdot \delta^{13} C-d e t
\end{aligned}
$$

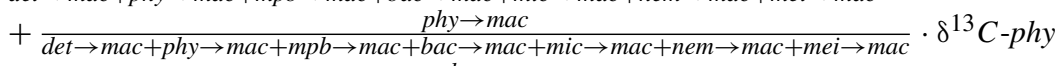

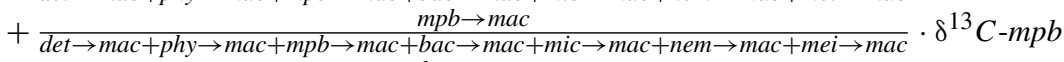

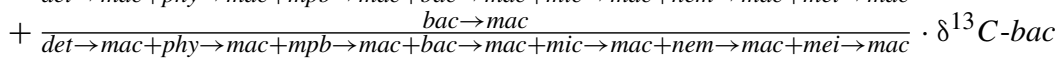

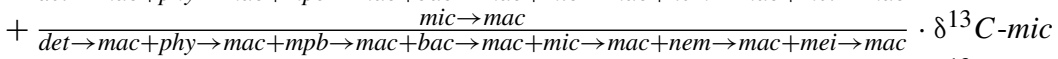

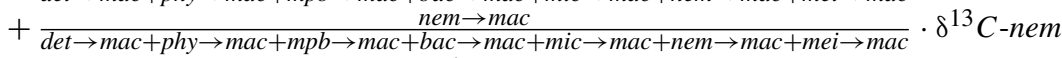

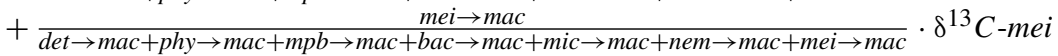

Equations

gross primary production $\quad$ dic $\rightarrow m p b=714$

bacterivory by microbenthos $b a c \rightarrow$ mic $=12.8$

sediment respiration $\quad m p b \rightarrow$ dic + bac $\rightarrow$ dic + mic $\rightarrow$ dic + nem $\rightarrow$ dic

+ mei $\rightarrow$ dic + mac $\rightarrow$ dic $=2112$

bacterial growth efficiency $\quad B G E d o c=2 \cdot B G E d e t$

bacterial production

$B G E d e t \cdot d e t \rightarrow b a c+B G E d o c \cdot d o c \rightarrow b a c=598$

maintenance respiration

$0.01 \cdot$ biomass 
Table A.2. Constraints imposed on the benthic food web. Sources are (1) Langdon (1993), (2) Goto et al. (1999), (3) del Giorgio and Cole (1998), (4) Verity (1985), (5) Zubkov and Sleigh (1999), (6) Capriulo (1990), (7) Fenchel (1982), (8) Straile (1997), (9) Herman and Vranken (1988), (10) Heip et al. (1985), (11) Woombs and Laybourn-Parry (1985), (12) Gerlach (1971), (13) Schiemer et al. (1980), (14) Vranken and Heip (1986), (15) Moens and Vincx (1997), (16) Landry et al. (1983), (17) Conover (1966), (18) Fleeger and Palmer (1982), (19) Feller (1982), (20) Herman and Heip (1985), (21) Banse and Mosher (1980), (22) Herman et al. (1983), (23) Herman et al. (1984), (24) Loo and Rosenberg (1996), (25) Arifin and Bendell-Young (1997), (26) Jordana et al. (2001), (27) Nielsen et al. (1995), (28) Sprung (1993), (29) Heip et al. (1995), (30) Thompson and Schaffner (2001), (31) Robertson (1979), (32) Calow (1977).

Process Flow/units

Lower boundary

Upper boundary

Sources

\section{microphytobenthos}

respiration

excretion

$$
\begin{array}{ll}
m p b \rightarrow \text { dic } & 0.16 \cdot d i c \rightarrow m p b \\
m p b \rightarrow \text { doc } & 0.42 \cdot d i c \rightarrow m p b
\end{array}
$$

$$
0.73 \cdot d i c \rightarrow m p b
$$

\section{bacteria}

${ }_{B G E d e t}{ }^{a}$

0.06

0.32

microbenthos

$A E^{b}$

$P B^{c}$

$\overline{\mathrm{d}^{-1}}$

0.91

1.0

4

$N G E^{d, e}$

0.50

5.0

5-7

0.10

0.50

\section{nematodes}

$A E^{b}$

$P B^{c}$

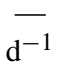

0.06

0.30

9-11

$N G E^{d}$

0.05

0.40

9,11-14

bacterivory $f$

0.60

0.90

9,10

grazing microbenthos ${ }^{f}$

herbivory $f$

bac $\rightarrow$ nem $\frac{\text { bac }}{b a c+m i c} \cdot \frac{n e m_{m i c}}{n e m} \cdot C_{n e m}$

predation $^{f}$

$$
\begin{gathered}
\text { mic } \rightarrow \text { nem } \quad \frac{\text { mic }}{\text { bac }+ \text { mic }} \cdot \frac{n e m_{\text {mic }}}{\text { nem }} \cdot C_{\text {nem }} \\
\text { mpb } \rightarrow \text { nem } \quad \frac{\text { nem emi }}{\text { nem }} \cdot C_{\text {nem }}
\end{gathered}
$$

\section{meiobenthos}

$\begin{array}{lcccc}A E^{b} & - & 0.57 & 0.77 & 16,17 \\ P B^{c} & \mathrm{~d}^{-1} & 0.03 & 0.09 & 18-22 \\ N G E^{d} & - & 0.30 & 0.50 & 20-23\end{array}$

\section{macrobenthos}

$\begin{array}{lcclr}A E^{b} & - & 0.40 & 0.75 & 24-26 \\ P B^{c} & \mathrm{~d}^{-1} & 0.01 & 0.05 & 24,27,28-31 \\ N G E^{d} & - & 0.50 & 0.70 & 27,32 \\ \text { suspension feeding }^{g} & p h y \rightarrow \text { mac } & \frac{\text { mac sus }}{\text { mac }} \cdot C_{\text {mac }} & & \end{array}$

${ }^{a}$ The range of $B G E d e t$ is determined from the range of values for seaweeds (del Giorgio and Cole, 1998), this range covers the range in $B G E$ for phytoplankton and faeces as well.

${ }^{b} A E$ is assimilation efficiency and is defined as $\frac{\sum \text { consumption-loss to detritus }}{\sum \text { consumption }}$.

${ }^{c} P B$ is production to biomass ratio. 
Table A.2. (Continued)

${ }^{d} N G E$ is net growth efficiency and is defined as $\frac{\sum \text { consumption-loss to detritus-respiration }}{\sum \text { consumption-loss to detritus }}$.

$e^{e}$ data on gross growth efficiency $(G G E)$ are the quartiles of the box-whisker plot for flagellates and ciliates in Straile (1997), i.e. $10 \%$ and $45 \%$. Subsequently net growth efficiency is calculated as $N G E=\frac{G G E}{A E}$.

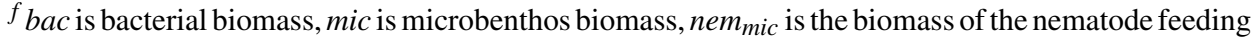
groups microvores and ciliate feeders, nem $_{e p i}$ is the biomass of the nematode epistrate feeding group, nem $_{\text {pre }}$ is the biomass of the nematode predator feeding group, nem $_{f a c}$ is the biomass of the nematode facultative predator feeding group, nem is nematode biomass and $C_{n e m}$ is the total consumption by nematodes.

$g_{\text {mac }}$ sus is the biomass of the macrobenthos suspension feeding group, mac is the macrobenthos biomass and $C_{m a c}$ is the total consumption by macrobenthos.

Table A.3. Model equations of the dynamic tracer model. FixRate is the observed fixation rate of microphytobenthos $\left(32 \mathrm{mg}^{13} \mathrm{C} \mathrm{m}^{-2} \mathrm{~h}^{-1}\right.$ during 4.5 hours). The tracer concentration in a compartment is denoted as stock ${ }^{\text {tr }}$. Abbreviations as in Figure 1.

$$
\begin{aligned}
& \tau_{i \rightarrow j}=\frac{\text { flow }_{i \rightarrow j}}{\text { stock }_{i}} \\
& \frac{d m p b^{t r}}{d t}=\Gamma \cdot \text { FixRate } \cdot\left(1-\frac{m p b \rightarrow d o c+m p b \rightarrow \text { dic }}{d i c \rightarrow m p b}\right) \\
& -m p b^{t r} \cdot\left(\tau_{m p b \rightarrow \text { det }}+\tau_{m p b \rightarrow \text { mic }}+\tau_{m p b \rightarrow \text { mem }}+\tau_{m p b \rightarrow m e i}+\tau_{m p b \rightarrow m a c}\right) \quad \text { with } \Gamma=\left\{\begin{array}{l}
0, \quad t>\frac{4.5}{24} \\
1, \quad t \leq \frac{4.5}{24}
\end{array}\right. \\
& \frac{d b a c^{t r}}{d t}=B G E d o c \cdot d o c^{t r} \cdot \tau_{d o c \rightarrow b a c}+B G E d e t \cdot \operatorname{det}^{t r} \cdot \tau_{\text {det } \rightarrow \text { bac }} \\
& -b_{a c}{ }^{t r} \cdot\left(\tau_{b a c \rightarrow d o c}+\tau_{b a c \rightarrow d e t}+\tau_{b a c \rightarrow b u r}+\tau_{b a c \rightarrow \text { mic }}+\tau_{b a c \rightarrow n e m}+\tau_{b a c \rightarrow m e i}+\tau_{b a c \rightarrow m a c}\right) \\
& \frac{d m i c^{t r}}{d t}=m p b^{t r} \cdot \tau_{m p b \rightarrow m i c}+\operatorname{bac}^{t r} \cdot \tau_{b a c \rightarrow m i c}+\operatorname{det}^{t r} \cdot \tau_{\text {det } \rightarrow \text { mic }}+\text { doc }^{t r} \cdot \tau_{\text {doc } \rightarrow \text { mic }} \\
& -\frac{\sum_{i} \text { stock }_{i}^{t r} \cdot \tau_{i \rightarrow \text { mic }}}{\sum_{i} \text { flow }_{i, \text { mic }}} \cdot\left(\tau_{\text {mic } \rightarrow \text { dic }}+\tau_{\text {mic } \rightarrow \text { det }}\right)-\text { mic }^{t r} \cdot\left(\tau_{\text {mic } \rightarrow \text { nem }}+\tau_{\text {mic } \rightarrow \text { mei }}+\tau_{\text {mic } \rightarrow \text { mac }}\right) \\
& \frac{d n e m^{t r}}{d t}=m p b^{t r} \cdot \tau_{m p b \rightarrow n e m}+b_{a c}{ }^{t r} \cdot \tau_{b a c \rightarrow n e m}+\text { mic }^{t r} \cdot \tau_{\text {mic } \rightarrow \text { nem }}+\text { det }^{t r} \cdot \tau_{\text {det } \rightarrow \text { nem }} \\
& -\frac{\sum_{i} \text { stock }_{i}^{\text {tr }} \cdot \tau_{i \rightarrow \text { nem }}}{\sum_{i} \text { flow }_{i, \text { nem }}} \cdot\left(\tau_{\text {nem } \rightarrow \text { dic }}+\tau_{\text {nem } \rightarrow \text { det }}\right)-\text { nem }^{\text {tr }} \cdot \tau_{\text {nem } \rightarrow \text { mac }} \\
& \frac{d m e i^{t r}}{d t}=m p b^{t r} \cdot \tau_{m p b \rightarrow m e i}+b a c^{t r} \cdot \tau_{b a c \rightarrow m e i}+m i c^{t r} \cdot \tau_{m i c \rightarrow m e i}+d e t^{t r} \cdot \tau_{d e t \rightarrow m e i} \\
& -\frac{\sum_{i} \text { stock }_{i}^{t r} \cdot \tau_{i \rightarrow m e i}}{\sum_{i} \text { flow }_{i, m e i}} \cdot\left(\tau_{m e i \rightarrow \text { dic }}+\tau_{m e i \rightarrow \text { det }}\right)-m e i^{t r} \cdot \tau_{m e i \rightarrow m a c} \\
& \frac{d m a c^{t r}}{d t}=m p b^{t r} \cdot \tau_{m p b \rightarrow m a c}+b a c^{t r} \cdot \tau_{b a c \rightarrow m a c}+m i c^{t r} \cdot \tau_{m i c \rightarrow m a c}+\text { nem }{ }^{t r} \cdot \tau_{n e m \rightarrow m a c} \\
& + \text { mei }^{t r} \cdot \tau_{\text {mei } \rightarrow \text { mac }}+\text { det }^{t r} \cdot \tau_{\text {det } \rightarrow \text { mac }}-\frac{\sum_{i} \text { stock }_{i}^{\text {tr }} \cdot \tau_{i \rightarrow \text { mac }}}{\sum_{i} \text { flow } \text { flmac }_{\text {mac }}} \cdot\left(\tau_{\text {mac } \rightarrow \text { dic }}+\tau_{\text {mac } \rightarrow \text { det }}\right) \\
& -m a c^{t r} \cdot \tau_{m a c \rightarrow \exp } \\
& \frac{d \text { doc }{ }^{t r}}{d t}=\Gamma \cdot \text { FixRate } \cdot \frac{m p b \rightarrow \text { doc }}{\text { dic } \rightarrow \text { mpb }}+\frac{\sum_{i} \text { stock }_{i}^{t r} \cdot \tau_{i \rightarrow b a c}}{\sum_{i} \text { flow }_{i, b a c}} \cdot \tau_{b a c \rightarrow \text { doc }}-\text { doc }^{t r} \cdot\left(\tau_{\text {doc } \rightarrow \text { bac }}+\tau_{\text {doc } \rightarrow \text { mic }}\right) \\
& \frac{d d e t^{t r}}{d t}=m p b^{t r} \cdot \tau_{m p b \rightarrow d e t}+b_{a c}{ }^{t r} \cdot \tau_{b a c \rightarrow d e t}+\sum_{i}\left(\text { stock }_{i}^{t r} \cdot \tau_{i \rightarrow \text { mic }}\right) \cdot \frac{\text { mic } \rightarrow \text { det }}{\sum_{i} \text { flow }_{i \rightarrow m i c}} \\
& +\sum_{i}\left(\text { stock }_{i}^{\text {tr }} \cdot \tau_{i \rightarrow \text { nem }}\right) \cdot \frac{\text { nem } \rightarrow \text { det }}{\sum_{i} \text { flow }_{i \rightarrow \text { nem }}}+\sum_{i}\left(\text { stock }_{i}^{\text {tr }} \cdot \tau_{i \rightarrow \text { mei }}\right) \cdot \frac{\text { mei } \rightarrow \text { det }}{\sum_{i} \text { flow }_{i \rightarrow m e i}} \\
& +\sum_{i}\left(\text { stock }_{i}^{t r} \cdot \tau_{i \rightarrow \text { mac }}\right) \cdot \frac{\text { mac } \rightarrow \text { det }}{\sum_{i} \text { flow }_{i \rightarrow \text { mac }}} \\
& -d e t^{t r} \cdot\left(\tau_{\text {det } \rightarrow \text { bac }}+\tau_{\text {det } \rightarrow \text { mic }}+\tau_{\text {det } \rightarrow \text { nem }}+\tau_{\text {det } \rightarrow \text { mei }}+\tau_{\text {det } \rightarrow \text { mac }}\right)
\end{aligned}
$$




\section{REFERENCES}

Alongi, D. M. 1995. Decomposition and recycling of organic matter in muds of the Gulf of Papua, Northern Coral Sea. Cont. Shelf Res., 15, 1319-1337.

Arifin, Z. and L. I. Bendell-Young. 1997. Feeding response and carbon assimilation by the blue mussel Mytilus trossulus exposed to environmentally relevant seston matrices. Mar. Ecol. Prog. Ser., 160, 241-253.

Azam, F., T. Fenchel, J. G. Field, J. S. Gray, L. A. Meyer-Reil and F. Thingstad. 1983. The ecological role of water-column microbes in the sea. Mar. Ecol. Prog. Ser., 10, 257-263.

Banse, K. and S. Mosher. 1980. Adult body mass and annual production/biomass relationships of field populations. Ecol. Monogr., 50, 355-379.

Blair, N. E., L. A. Levin, D. J. DeMaster and G. Plaia. 1996. The short-term fate of fresh algal carbon in continental slope sediments. Limnol. Oceanogr., 41, 1208-1219.

Boschker, H. T. S., J. F. C. De Brouwer and T. E. Cappenberg. 1999. The contribution of macrophytederived organic matter to microbial biomass in salt-marsh sediments: Stable carbon isotope analysis of microbial biomarkers. Limnol. Oceanogr., 44, 309-319.

Boschker, H. T. S. and J. J. Middelburg. 2002. Stable isotopes and biomarkers in microbial ecology. FEMS Microbiol. Ecol., 40, 85-95.

Bouillon, S. and H. T. S. Boschker. 2006. Bacterial carbon sources in coastal sediments: A crosssystem analysis based on stable isotope data of biomarkers. Biogeosciences, 3, 175-185.

Bouillon, S., T. Moens, N. Koedam, F. Dahdouh-Guebas, W. Baeyens and F. Dehairs. 2004. Variability in the origin of carbon substrates for bacterial communities in mangrove sediments. FEMS Microbiol. Ecol., 49, 171-179.

Breed, G. A., G. A. Jackson and T. L. Richardson. 2004. Sedimentation, carbon export and food web structure in the Mississippi River plume described by inverse analysis. Mar. Ecol. Prog. Ser., 278, 35-51.

Burke, R. A., M. Molina, J. E. Cox, L. J. Osher and M. C. Piccolo. 2003. Stable carbon isotope ratio and composition of microbial fatty acids in tropical soils. J. Environ. Qual., 32, 198206.

Calow, P. 1977. Conversion efficiencies in heterotrophic organisms. Biol. Rev., 52, 385-409.

Cammen, L. 1991. Annual bacterial production in relation to benthic microalgal production and sediment oxygen uptake in an intertidal sandflat and intertidal mudflat. Mar. Ecol. Prog. Ser., 71, 13-25.

Canfield, D. E., B. B. Jorgensen, H. Fossing, R. Glud, J. Gundersen, N. B. Ramsing, B. Thamdrup, J. W. Hansen, L. P. Nielsen and P. O. J. Hall. 1993. Pathways of organic-carbon oxidation in three continental-margin sediments. Mar. Geol., 113, 27-40.

Capriulo, G. M. 1990. Feeding-related ecology of marine protozoa, in Ecology of Marine Protozoa, G. M. Capriulo, ed., Oxford University Press, NY, 186-259.

Chanton, J. and F. G. Lewis. 2002. Examination of coupling between primary and secondary production in a river-dominated estuary: Apalachicola Bay, Florida, USA. Limnol. Oceanogr., 47, 683-697.

Chardy, P. and J.-C. Dauvin. 1992. Carbon flows in a subtidal fine sand community from the western English Channel: A simulation analysis. Mar. Ecol. Prog. Ser., 81, 147-161.

Cole, J. J., S. R. Carpenter, J. F. Kitchell and M. L. Pace. 2002. Pathways of organic carbon utilization in small lakes: Results from a whole-lake C-13 addition and coupled model. Limnol. Oceanogr., 47, 1664-1675.

Conover, R. J. 1966. Factors affecting the assimilation of organic matter by zooplankton and the question of superfluous feeding. Limnol. Oceanogr., 11, 346-354. 
Dauwe, B., J. J. Middelburg and P. M. J. Herman. 2001. Effect of oxygen on the degradability of organic matter in subtidal and intertidal sediments of the North Sea area. Mar. Ecol. Prog. Ser., 215, 13-22.

Dauwe, B., J. J. Middelburg, P. Van Rijswijk, J. Sinke, P. M. J. Herman and C. H. R. Heip. 1999. Enzymatically hydrolyzable amino acids in North Sea sediments and their possible implication for sediment nutritional values. J. Mar. Res., 57, 109-134.

del Giorgio, P. A. and J. J. Cole. 1998. Bacterial growth efficiency in natural aquatic systems. Annu. Rev. Ecol. Syst., 29, 503-541.

DeNiro, M. J. and S. Epstein. 1977. Mechanisms of carbon isotope fractionation associated with lipid synthesis. Science, 197, 261-263.

Eldridge, P. M., L. A. Cifuentes and J. E. Kaldy. 2005. Development of a stable-isotope constraint system for estuarine food-web models. Mar. Ecol. Prog. Ser., 303, 73-90.

Epstein, S. S. and M. P. Shiaris. 1992. Rates of microbenthic and meiobenthic bacterivory in a temperate muddy tidal flat community. Appl. Environ. Microbiol., 58, 2426-2431.

Feller, R. J. 1982. Empirical estimates of carbon production for a meiobenthic harpacticoid copepod. Can. J. Fish. Aquat. Sci., 39, 1435-1443.

Fenchel, T. 1982. Ecology of heterotrophic microflagellates. II Bioenergetics and growth. Mar. Ecol. Prog. Ser., 8, 225-231.

Fischer, U. R., C. Wieltschnig, A. K. T. Kirschner and B. Velimirov. 2003. Does virus-induced lysis contribute significantly to bacterial mortality in the oxygenated sediment layer of shallow oxbow lakes? Appl. Environ. Microbiol., 69, 5281-5289.

Fleeger, J. W. and M. A. Palmer. 1982. Secondary production of the estuarine, meiobenthic copepod Microarthridion littorale. Mar. Ecol. Prog. Ser., 7, 157-162.

Gerlach, S. A. 1971. On the importance of marine meiofauna for benthos communities. Oecologia, 6, 176-190.

Goto, N., T. Kawamura, O. Mitamura and H. Terai. 1999. Importance of extracellular organic carbon production in the total primary production by tidal-flat diatoms in comparison to phytoplankton. Mar. Ecol. Prog. Ser., 190, 289-295.

Grutters, M., W. van Raaphorst, E. Epping, W. Helder, J. W. de Leeuw, D. P. Glavin and J. Bada. 2002. Preservation of amino acids from in situ-produced bacterial cell wall peptidoglycans in northeastern Atlantic continental margin sediments. Limnol. Oceanogr., 47, 1521-1524.

Hamels, I., T. Moens, K. Mutylaert and W. Vyverman. 2001a. Trophic interactions between ciliates and nematodes from an intertidal flat. Aquat. Microb. Ecol., 26, 61-72.

Hamels, I., K. Muylaert, G. Casteleyn and W. Vyverman. 2001b. Uncoupling of bacterial production and flagellate grazing in aquatic sediments: A case study from an intertidal flat. Aquat. Microb. Ecol., 25, 31-42.

Hamels, I., K. Sabbe, K. Muylaert, C. Barranguet, C. H. Lucas, P. M. J. Herman and W. Vyverman. 1998. Organisation of microbenthic communities in intertidal estuarine flats, a case study from the Molenplaat (Westerschelde Estuary, The Netherlands). Eur. J. Protistol., 34, 308-320.

Hamels, I., K. Sabbe, K. Muylaert and W. Vyverman. 2004. Quantitative importance, composition, and seasonal dynamics of protozoan communities in polyhaline versus freshwater intertidal sediments. Microb. Ecol., 47, 18-29.

Hayes, J. M. 2001. Fractionation of carbon and hydrogen isotopes in biosynthetic processes, in Stable Isotope Geochemistry, 43, Reviews in Mineralogy and Geochemistry, J. Valley and D. Cole, ed., Mineralogical Society of America, 1st edition. 225-277.

Heip, C. H. R., N. K. Goosen, P. M. J. Herman, J. Kromkamp, J. J. Middelburg and K. Soetaert. 1995. Production and consumption of biological particles in temperate tidal estuaries. Oceanogr. Mar. Biol. Ann. Rev., 33, 1-149. 
Heip, C., M. Vincx and G. Vranken. 1985. The ecology of marine nematodes. Oceanogr. Mar. Biol. Ann. Rev., 23, 399-489.

Herman, P. M. J. and C. Heip. 1985. Secondary production of the harpacticoid copepod Paronychocamptus nanus in a brackish-water habitat. Limnol. Oceanogr., 30, 1060-1066.

Herman, P. M. J., C. Heip and B. Guillemijn. 1984. Production of Tachidius discipes (Copepoda: Harpacticoida). Mar. Ecol. Prog. Ser., 17, 271-278.

Herman, P. M. J., C. Heip and G. Vranken. 1983. The production of Cyprideis torosa Jones 1850 (Crustacea, Ostracoda). Oecologia, 58, 326-331.

Herman, P. M. J., J. J. Middelburg and C. H. R. Heip. 2001. Benthic community structure and sediment processes on an intertidal flat: Results from the ECOFLAT project. Cont. Shelf Res., 21, 2055-2071.

Herman, P. M. J., J. J. Middelburg, J. Van de Koppel and C. H. R. Heip. 1999. Ecology of estuarine macrobenthos. Adv. Ecol. Res., 29, 195-240.

Herman, P. M. J. and G. Vranken. 1988. Studies of the life-history and energetics of marine and brackish-water nematodes. 2. Production, respiration and food uptake by Monhystera disjuncta. Oecologia, 77, 457-463.

Herman, P. M. J., J. J. Middelburg, J. Widdows, C. H. Lucas and C. H. R. Heip, 2000. Stable isotopes as trophic tracers: Combining field sampling and manipulative labelling of food resources for macrobenthos. Mar. Ecol. Prog. Ser., 204, 79-92.

Hondeveld, B. J. M., G. Nieuwland, F. C. Van Duyl and R. P. M. Bak. 1995. Impact of nanoflagellate bacterivory on benthic bacterial production in the North Sea. Neth. J. Sea Res., 34, 275-287.

Jackson, G. A. and P. M. Eldridge. 1992. Food web analysis of a planktonic system off Southern California. Prog. Oceanogr., 30, 223-251.

Jordana, E., F. Charles, A. Gremare, J. M. Amouroux and M. J. Chretiennot-Dinet. 2001. Food sources, ingestion and absorption in the suspension-feeding polychaete, Ditrupa arietina (O.F. Muller). J. Exp. Mar. Biol. Ecol., 266, 219-236.

Jumars, P. A., D. L. Penry, J. A. Baross, M. J. Perry and B. W. Frost. 1989. Closing the microbial loop-Dissolved carbon pathway to heterotrophic bacteria from incomplete ingestion, digestion and absorption in animals. Deep-Sea Res. I, 36, 483-495.

Kemp, P. F. 1987. Potential impact on bacteria of grazing by a macrofaunal deposit-feeder, and the fate of bacterial production. Mar. Ecol. Prog. Ser., 36, 151-161.

1990. The fate of benthic bacterial production. Aquat. Sci., 2, 109-124.

Klepper, O. and J. P. G. Van de Kamer. 1987. The use of mass balances to test and improve the estimates of carbon fluxes in an ecosystem. Math. Biosci., 85, 37-49.

Kones, J., K. Soetaert, D. van Oevelen, J. O. Owino and K. Mavuti. 2006. Gaining insight into food webs reconstructed by the inverse method. J. Mar. Syst., 60, 153-166.

Landry, M. R., R. P. Hasset, V. Fagerness, J. Downs and C. J. Lorenzen. 1983. Effect of food acclimation on assimilation efficiency of Calanus pacificus. Limnol. Oceangr., 29, 361-364.

Langdon, C. 1993. The significance of respiration in production measurements based on oxygen. ICES Mar. Sci. Symp., 197, 69-78.

Legendre, L. and F. Rassoulzadegan. 1995. Plankton and nutrient dynamics in marine waters. Ophelia, 41, 153-172.

Levin, L. A., N. E. Blair, C. M. Martin, D. J. DeMaster, G. Plaia and C. J. Thomas. 1999. Macrofaunal processing of phytodetritus at two sites on the Carolina margin: In situ experiments using ${ }^{13} \mathrm{C}$-labeled diatoms. Mar. Ecol. Prog. Ser., 182, 37-54.

Loo, L.-O. and R. Rosenberg. 1996. Production and energy budget in marine suspension feeding populations: Mytilus edulis, Cerastoderma edule, Mya arenaria and Amphiura filiformis. J. Sea Res., 35, 199-207. 
Mayer, L. M., P. A. Jumars, M. J. Bock, Y.-A. Vetter and J. L. Schmidt. 2001. Two roads to sparagmos: Extracellular digestion of sedimentary food by bacterial inoculation versus deposit-feeding, in Organism-Sediment Interactions, J. Y. Aller, S. A. Woodin and R. C. Aller, eds. University of South Carolina Press, 335-347.

Menke, W. 1984. Geophysical data analysis: Discrete inverse theory. Academic Press, New York.

Middelburg, J. J., C. Barranguet, H. T. S. Boschker, P. M. J. Herman, T. Moens and C. H. R. Heip. 2000. The fate of intertidal microphytobenthos: An in situ ${ }^{13} \mathrm{C}$ labeling study. Limnol. Oceanogr., 45, 1224-1234.

Moens, T., C. Luyten, J. J. Middelburg, P. M. J. Herman and M. Vincx. 2002. Tracing organic matter sources of estuarine tidal flat nematodes with stable carbon isotopes. Mar. Ecol. Prog. Ser., 234, $127-137$.

Moens, T. and M. Vincx. 1997. Observations on the feeding ecology of estuarine nematodes. J. Mar. Biol. Assoc. U.K., 77, 211-227.

Moodley, L., J. J. Middelburg, H. T. S. Boschker, G. C. A. Duineveld, R. Pel, P. M. J. Herman and C. H. R. Heip. 2002. Bacteria and foraminifera: Key players in a short-term deep-sea benthic response to phytodetritus. Mar. Ecol. Prog. Ser., 236, 23-29.

Nielsen, A. M., N. T. Eriksen, J. J. L. Iversen and H. U. Riisgård. 1995. Feeding, growth and respiration in the polychaetes Nereis diversicolor (facultative filter-feeder) and N. virens (omnivorous) - A comparative study. Mar. Ecol. Prog. Ser., 125, 149-158.

Niquil, N., G. A. Jackson, L. Legendre and B. Delesalle. 1998. Inverse model analysis of the planktonic food web of Takapoto Atoll (French Polynesia). Mar. Ecol. Prog. Ser., 165, 17-29.

Paul, J. H., J. B. Rose, S. C. Jiang, C. A. Kellogg and L. Dickson. 1993. Distribution of viral abundance in the reef environment of Key Largo, Florida. Appl. Environ. Microbiol., 59, 718-724.

Phillips, D. L. 2001. Mixing models in analyses of diet using multiple stable isotopes: A critique. Oecologia, 127, 166-170.

Phillips, D. L. and J. W. Gregg. 2003. Source partitioning using stable isotopes: Coping with too many sources. Oecologia, 136, 261-269.

Polis, G. A. and D. R. Strong. 1996. Food web complexity and community dynamics. Am. Nat., 147, 813-846.

Post, D. M. 2002. Using stable isotopes to estimate trophic position: Models, methods, and assumptions. Ecology, 83, 703-718.

Robertson, A. I. 1979. The relationship between annual production : biomass ratios and lifespans for marine macrobenthos. Oecologia, 38, 193-202.

Ryther, J. H. 1969. Photosynthesis and fish production in the sea. Science, 166, 72-76.

Schiemer, F., A. Duncan and R. Z. Klekowski. 1980. A bioenergetic study of a benthic nematode, Plectus palustris de Man 1880, throughout its life cycle. Oecologia, 44, 205-212.

Schwinghamer, P. 1981. Characteristic size distributions of integral benthic communities. Can. J. Fish. Aquat. Sci., 38, 1255-1263.

Schwinghamer, P., B. Hargrave, D. Peer and C. M. Hawkins. 1986. Partitioning of production and respiration among size groups of organisms in an intertidal benthic community. Mar. Ecol. Prog. Ser., 31, 131-142.

Sherr, E. B. 1988. Direct use of high molecular-weight polysaccharide by heterotrophic flagellates. Nature, 335, 348-351.

Smith, K. L. 1973. Respiration of a sublittoral community. Ecology, 54, 1065-1075.

Sobczak, W. V., J. E. Cloern, A. D. Jassby and A. B. Muller-Solger. 2002. Bioavailability of organic matter in a highly disturbed estuary: The role of detrital and algal resources. Proc. Natl. Acad. Sci. U. S. A., $99,8101-8105$. 
Soetaert, K., V. deClippele and P. M. J. Herman. 2002. FEMME, a flexible environment for mathematically modelling the environment. Ecol. Model., 151, 177-193.

Soetaert, K., M. Vincx, J. Wittoeck and M. Tulkens. 1995. Meiobenthic distribution and nematode community structure in 5 European estuaries. Hydrobiologia, 311, 185-206.

Sprung, M. 1993. Estimating macrobenthic secondary production from body weight and biomass: A field test in a non-boreal intertidal habitat. Mar. Ecol. Prog. Ser., 100, 103-109.

Steele, J. H. 1974. The Structure of Marine Ecosystems. Cambridge University Press, Cambridge, $128 \mathrm{pp}$.

Steyaert, M., J. Vanaverbeke, A. Vanreusel, C. Barranguet, C. Lucas and M. Vincx. 2003. The importance of fine-scale, vertical profiles in characterising nematode community structure. Estuar. Coast. Shelf Sci., 58, 353-366.

Stone, L., T. Berman, R. Bonner, S. Barry and S. W. Weeks. 1993. Lake Kinneret: A seasonal model for carbon flux through the planktonic biota. Limnol. Oceanogr., 38, 1680-1695.

Straile, D. 1997. Gross growth efficiencies of protozoan and metazoan zooplankton and their dependence on food concentration, predator-prey weight ratio, and taxonomic group. Limnol. Oceanogr., 42, 1375-1385.

Tank, J. L., J. L. Meyer, D. M. Sanzone, P. J. Mulholland, J. R. Webster, B. J. Peterson, S. A. Woodin and N. E. Leonard. 2000. Analysis of nitrogen cycling in a forest stream during autumn using a ${ }^{15} \mathrm{~N}$-tracer addition. Limnol. Oceanogr., 45, 1013-1029.

Teal, J. M. 1962. Energy flow in the salt marsh ecosystem of Georgia. Ecology, 43, 614-649.

Teece, M. A., M. L. Fogel, M. E. Dollhopf and K. H. Nealson. 1999. Isotopic fractionation associated with biosynthesis of fatty acids by a marine bacterium under oxic and anoxic conditions. Org. Geochem., 30, 1571-1579.

Thompson, M. L. and L. C. Schaffner. 2001. Population biology and secondary production of the suspension feeding polychaete Chaetopterus cf. variopedatus: Implications for benthic-pelagic coupling in lower Chesapeake Bay. Limnol. Oceanogr., 46, 1899-1907.

Van den Meersche, K., J. J. Middelburg, K. Soetaert, P. Van Rijswijk, H. T. S. Boschker and C. H. R. Heip. 2004. Carbon-nitrogen coupling and algal-bacterial interactions during an experimental bloom: Modeling a ${ }^{13} \mathrm{C}$ tracer experiment. Limnol. Oceanogr., 49, 862-878.

Van Duyl, F. C. and A. J. Kop. 1990. Seasonal patterns of bacterial production and biomass in intertidal sediments of the western Dutch Wadden Sea. Mar. Ecol. Prog. Ser., 29, 249-261.

Van Oevelen, D., J. J. Middelburg, K. Soetaert and L. Moodley. 2006. Fate of bacterial carbon in an intertidal sediment: Modeling an in situ isotope tracer experiment. Limnol. Oceanogr., 51, 1302-1314.

Vanderbei, R. J. 1996. Linear Programming: Foundations and Extensions, 4th ed., Kluwer Academic Publishers, Boston, MA.

Verity, P. G. 1985. Grazing, respiration, excretion, and growth rates of tintinnids. Limnol. Oceanogr., 30, 1268-1282.

Vézina, A. F., F. Berreville and S. Loza. 2004. Inverse reconstructions of ecosystem flows in investigating regime shifts: Impact of the choice of objective function. Prog. Oceanogr., 60, 321-341.

Vézina, A. F. and M. Pahlow. 2003. Reconstruction of ecosystem flows using inverse methods: How well do they work? J. Mar. Syst., 40, 55-77.

Vézina, A. F. and T. Platt. 1988. Food web dynamics in the ocean. I. Best-estimates of flow networks using inverse methods. Mar. Ecol. Prog. Ser., 42, 269-287.

Vranken, G. and C. Heip. 1986. The productivity of marine nematodes. Ophelia, 26, 429-442.

Witte, U., F. Wenzhofer, S. Sommer, A. Boetius, P. Heinz, N. Aberle, M. Sand, A. Cremer, W. R. Abraham, B. B. Jorgensen and O. Pfannkuche. 2003. In situ experimental evidence of the fate of a phytodetritus pulse at the abyssal sea floor. Nature, 424, 763-766. 
Woombs, M. and J. Laybourn-Parry. 1985. Energy partitioning in three species of nematode from polysaprobic environments. Oecologia, 65, 289-295.

Wunsch, C. and J. F. Minster. 1982. Methods for box models and ocean circulation tracers: Mathematical programming and nonlinear inverse theory. J. Geophys. Res., 87, 5647-5662.

Zubkov, M. V. and M. A. Sleigh. 1999. Growth of amoebae and flagellates on bacteria deposited on filters. Microb. Ecol., 37, 107-115.

Received: 31 August, 2005; revised: 30 March, 2006. 